\title{
Manajemen Asuhan Keperawatan Psikososial Dengan Masalah Kecemasan Pada Pasien Hipertensi Kehamilan
}

\author{
Marisa Juniar E.S \\ marisasaragih551@gmail.com
}

BAB 1

PENDAHULUAN

\subsection{Latar Belakang}

Hipertensi merupakan salah satu penyebab kematian tertinggi pada masyarakat juga the sllent killer. Hipertensi menjadi salah satufokus perhatian kesehatan dunia,terutama dinegara berkembang penyebab keseakitan serta kematian yang tinggi seluruh dunia (Dewi \& Sudhana, 2015). Hipertensi merupakan tekanan darah tinggi sitolik $>140 \mathrm{mmHg}$ dan diastolik >90 mmHg (Yuwono, Ridwan \& Hanafi,2017). Berdasarkan hasil riskesdes pada tahun 2018 angka terjadinya Hipertensi pada kehamilan diindonesia yakni (31\%). Beberapa kota dengan presentasi hasil cukup besar mempunyai penyakit hipertensi pada kehamilan diantaranya: Jawa Barat (12\%), Sumatra Barat (9\%), Sumatra Utara (10\%).

Tekanan darah tingg pada ibu hamil dapat berdampak pada pertumbuhan janin yang tidak sempurna, prematur, lahir dengan berat rendah, bahkan kematian ibu dan bayi. Pada ibu hamil menderita kecemasan yang dirasakan dapat mempengaruhi kondisi psikologis ibu bahkan samapi kekondisi janin(Ariyanti \& yulianti, 2020). Salah satu penyebab terjadinya hipertensi adalah kecemasan yang diderita oleh individu, hal ini disebabkan reaksi yang muncul terhadap stressor yakni tekanan darahnya meningkat (Trisiani \& Hikmawati, 2016). 
Kecemasan merupakan respon tubuh terhadap peristiwa yang terjadi, dimana respons tubuh terhadap peristiwa yang terjadi, dimana respon tubuh tersebut lebih bersifat negatif sehingga menimbulkan ketidaknyamanan bagi klien (Zaini, 2019). Menurut DepKes RI, kecemasan adalah ketegangan, rasa tidak aman dan kekhawatiran yang timbul karena dirasakan terjadi sesuatu yang tidak menyenangkan tetapi sumbernya sebagian besar tidak diketahui dan berasal dari dalam (Wahyuni, 2018)

Kecemasan yang dirasakan dapat mempengaruhi kondisi psikologis ibu bahkan sampe kejanin. Ibu hamil dengan hipertensi memiliki rasa cemas senantiasa berpikir tentang keberlangsungan kehidupan janin hingga masa persalinan. Kecemaasan yang dirasakan ibu hamil akan berdampak pada janin dan kandungannya (Alatas,2019) ). Kecemasan dan kekhawatiran pada ibu hamil apabila tidak ditangani secara serius akan membawa dampak dan pengaruh terhadap fisik dan psikis, baik pada ibu maupun janin salah satunya adalah kegawatdaruratan saat persalinan lepasnya hormon stress yang menyebabkan vasokontriksi aliran darah dalam rahim.

\subsection{Tujuan Penulisan}

\section{Tujuan Umum}

Untuk memberikan asuhan keperawatan pada Ny.E dengan masalah kecemasan.

\section{Tujuan Khusus}

a. Mahasiswa mampu melakukan pengkajian pada Ny.E dengan masalah kecemasan.

b. Mahasiswa mampu menegakkan diagnosa pada Ny.E dengan masalah kecemasan.

c. Mahasiswa mampu membuat intervensi pada Ny.E dengan masalah kecemasan.

d. Mahasiswa mampu melakukan implementasi pada Ny.E dengan masalah kecemasan.

e. Mahasiswa mampu membuat evaluasi pada Ny.E dengan masalah kecemasan. 


\section{BAB 2}

\section{TINJAUAN TEORITIS}

\subsection{Konsep Hipertensi Pada Ibu Hmail}

\subsubsection{Defensi}

Hipertensi merupakan suatu tekanan darah abnormal di dalam arteri. Berdasarkan JNC VII, hipertensi tingkat 1 didapatkan jika tekanan darah sistolik $\geq 140$ dan atau diastolik $\geq 90 \mathrm{mmHg}$. Hipertensi dalam kehamilan adalah tekanan darah mencapai 140/90 $\mathrm{mmHg}$ atau lebih yang terjadi saat kehamilan. Pengukuran tekanan darah dilakukan secara dua kali setelah pasien beristirahat beberapa menit dengan menggunakan fase $\mathrm{V}$ Korotkoff untuk menentukan tekanan diastolik. Gold standart untuk memeriksa tekanan darah adalah memakai sphygmomanometer (Kemenkes, 2017)

Edema tidak lagi digunakan sebagai kriteria diagnostik karena kelainan ini terjadi pada banyak wanita hamil normal sehingga tidak lagi dapat digunakan sebagai faktor pembeda. Dahulu direkomendasikan bahwa yang digunakan sebagai kriteria diagnostik adalah peningkatan tekanan darah sistolik sebesar $30 \mathrm{mmHg}$ atau diastolik $15 \mathrm{mmHg}$, bahkan apabila angka absolut dibawah 140/90 $\mathrm{mmHg}$. Kriteria ini tidak lagi dianjurkan karena bukti memperlihatkan bahwa wanita dalam kelompok ini kecil kemungkinannya mengalami gangguan hasil kehamilan (Nadar, 2015)

\subsubsection{Klasifikasi hipertensi pada kehamilan}

Hipertensi pada kehamilan apabila tekanan darahnya $\geq 140 / 90 \mathrm{mmHg}$. Dibagi menjadi ringan-sedang (140 - 159 / 90 - 109 mmHg) dan berat ( $\geq 160 / 110 \mathrm{mmHg}$ ) (Malha, 2018). Hipertensi pada kehamilan dapat digolongkan menjadi: 1) pre-eklampsia/ eklampsia, 2) hipertensi kronis pada kehamilan, 3) hipertensi kronis disertai preeklampsia, dan 4) hipertensi gestational (Malha, 2018). 


\section{Pre-eklampsia dan Eklampsia}

Pre-eklampsia adalah sindrom pada kehamilan (>20 minggu), hipertensi ( $\geq 140 / 90 \mathrm{mmHg}$ ) dan proteinuria ( $>0,3 \mathrm{~g} /$ hari). Terjadi pada 2-5\% kehamilan dan angka kematian ibu 12-15\% (Malha, 2018). Pre-eklampsia juga dapat disertai gejala sakit kepala, perubahan visual, nyeri epigastrium, dan dyspnoea. Beberapa faktor telah diidentifikasi terkait dengan peningkatan risiko preeklampsia seperti usia, paritas, pre-eklampsia sebelumnya, riwayat keluarga, kehamilan ganda, kondisi medis yang sudah ada sebelumnya (diabetes mellitus tipe I), obesitas dan resistensi insulin, hipertensi kronis, penyakit 6 ginjal, penyakit autoimun, sindrom anti-fosfolipid, penyakit rematik), merokok, peningkatan indeks massa tubuh (BMI), peningkatan tekanan darah, dan proteinuria. Selain itu, beberapa faktor yang terkait termasuk keterpaparan sperma yang terbatas, primipaternitas, kehamilan setelah inseminasi donor / sumbangan oosit / embrio telah ditemukan memainkan peran penting pada kejadian preeklampsia/eklampsia (Karthikeyan, 2015).

2. Hipertensi kronis pada kehamilan

Hipertensi kronis pada kehamilan apabila tekanan darahnya $\geq 140 / 90 \mathrm{mmHg}$, terjadi sebelum kehamilan atau ditemukan sebelum 20 minggu kehamilan. Seringkali merupakan hipertensi esensial / primer, dan didapatkan pada 3,6-9\% kehamilan (Malha, 2018). Hipertensi kronis pada kehamilan adalah hipertensi $(\geq$ 140/90 mmHg) yang telah ada sebelum kehamilan. Dapat juga didiagnosis sebelum minggu ke-20 kehamilan. Ataupun yang terdiagnosis untuk pertama kalinya selama kehamilan dan berlanjut ke periode post-partum (Karthikeyan, 2015). Peningkatan tekanan darah pada hipertensi kronis terjadi sebelum minggu ke-20 kehamilan, dapat bertahan lama sampai lebih dari 12 minggu pasca persalinan (Leeman, 2016). Hipertensi, obesitas dan usia merupakan faktor risiko hipertensi kronis. Hipertensi 
kronis pada kehamilan meningkatkan risiko pre-eklampsia, 10 pertumbuhan janin, persalinan dini, dan kelahiran dengan ceasar (Seely and Ecker, 2015).

3. Hipertensi kronis yang disertai pre-eklampsia

Orang dengan hipertensi sebelum kehamilan (hipertensi kronis) memiliki risiko 4-5 kali terjadi pre-eklampsia pada kehamilannya. Angka kejadian hipertensi kronis pada kehamilan yang disertai pre-eklampsia sebesar 25\%. Sedangkan bila tanpa hipertensi kronis angka kejadian pre-eklampsia hanya 5\% (Malh, 2018). Hipertensi yang disertai pre-eklampsia biasanya muncul antara minggu 24-26 kehamilan berakibat kelahiran preterm dan bayi lebih kecil dari normal (IUGR) (Khosravi, 2016).

4. Hipertensi gestasional

Hipertensi gestasional adalah hipertensi yang terjadi setelah 20 minggu kehamilan tanpa proteinuria. Angka kejadiannya sebesar $6 \%$. Sebagian wanita (> 25\%) berkembang menjadi pre-eklampsia diagnosis hipertensi gestasional biasanya diketahui setelah melahirkan (Leslie and Collins, 2016; Malha, 2018). Hipertensi gestasional berat adalah kondisi peningkatan tekanan darah > 160/110 mmHg. Tekanan darah baru menjadi normal pada post partum, biasanya dalam sepuluh hari. Pasien mungkin mengalami sakit kepala, penglihatan kabur, dan sakit perut dan tes laboratorium abnormal, termasuk jumlah trombosit rendah dan tes fungsi hati abnormal (Karthikeyan, 2015). Hipertensi gestasional terjadi setelah 20 minggu kehamilan tanpa adanya proteinuria. Kelahiran dapat berjalan normal walaupun tekanan darahnya tinggi. Penyebabnya belum jelas, tetapi merupakan indikasi terbentuknya hipertensi kronis di masa depan sehingga perlu diawasi dan dilakukan tindakan pencegahan (Roberts, 2016). 


\subsubsection{Patologi hipertensi pada kehamilan}

Pre-eklampsia/eklampsia dapat terjadi karena faktor genetik. Bila seseorang memiliki riwayat keluarga pre-eklampsia/eklampsia maka dia mempunyai risiko lebih besar mengalami pre-eklampsia/eklampsia saat kehamilan (Ward and Lindheimer, 2018). Pre-eklampsia disebabkan oleh adanya plasenta atau respons ibu terhadap plasenta. Plasenta yang buruk adalah faktor predisposisi kuat yang mempengaruhi ibu, terkait dengan sinyal inflamasi (tergantung pada gen janin) dan juga sifat respons ibu (tergantung pada gen ibu) (Karthikeyan, 2017).

Pada kehamilan normal, arteri spiral uteri invasiv ke dalam trofoblas, menyebabkan peningkatan aliran darah dengan lancar untuk kebutuhan oksigen dan nutrisi janin. Pada pre-eklampsia, terjadi gangguan sehingga aliran darah tidak 15 lancar dan terjadi gangguan pada plasenta. Peningkatan sFlt1 (lihat Gambar) menyebabkan plasenta memproduksi free vascular endothelial growth factor (VEGF) dan penurunan placental growth factor (PlGF). Selanjutnya menyebabkan disfungsi endotel pada pembuluh ibu mengakibatkan penyakit multiorgan : hypertension, glomerular dysfunction, proteinuria, brain edema, liver edema, coagulation abnormalities (Malha, 2018). Terdapat dua teori pre-eklampsia, vaskular (iskemiareperfusi yang menghasilkan stres oksidatif dan penyakit vaskular) dan kekebalan tubuh (maladaptasi kekebalan ibu-ayah, yaitu reaksi alloimun maternal yang dipicu oleh penolakan terhadap allograft janin) yang dicurigai bertanggung jawab terhadap preeklampsia. Etiopatofisiologi pre-eklampsia sangat kompleks dan melibatkan beragam faktor seperti predisposisi genetik, gangguan pada reninangiotensinaldosteron, disfungsi endotelium ibu, koagulopati maternal, sitokinin, faktor pertumbuhan, dan sebagainya (Karthikeyan, 2015). 


\subsubsection{Pengobatan Hipertensi Pada Kehamilan}

Studi tentang pengobatan hipertensi pada kehamilan menggunakan sistematik review dan meta analisis yang melibatkan 14 studi (1804 wanita hamil) didapatkan bahwa penggunaan obat antihipertensi ternyata tidak mengurangi atau meningkatkan risiko kematian ibu, proteinuria, efek samping, operasi caesar, kematian neonatal, kelahiran prematur, atau bayi lahir kecil. Penelitian mengenai obat antihipertensi pada kehamilan masih sedikit (Ogura et al., 2019). Hipertensi pada kehamilan harus dikelola dengan baik agar dapat menurunkan angka morbiditas dan mortalitas ibu / janin, yaitu dengan menghindarkan ibu dari risiko peningkatan tekanan darah, mencegah perkembangan penyakit, dan mencegah timbulnya kejang dan pertimbangan terminasi kehamilan jika ibu atau janin dalam keadaan bahaya (Mudjari and Samsu, 2015). Kelahiran bayi adalah pengobatan yang pasti, tetapi perlu mempertimbangkan kesehatan ibu, janin, usia kehamilan. Pre-eklampsia berat membutuhkan kontrol dan pemantauan tekanan darah secara teratur. Pada kondisi kritis dokter anestesi dapat dilibatkan (Karthikeyan, 2015).

Penderita hipertensi pada kehamilan dan pre-eklampsia ringan disarankan melakukan partus pada minggu ke-37. Pada pre-eklampsia berat disarankan profilaksis magnesium sulfat dan waspada terjadinya hipertensi pasca persalinan (Leeman, 2016; Williams, 2018). Obat yang umum digunakan dalam pengobatan hipertensi pada kehamilan adalah labetalol, methyldopa, nifedipine, clonidine, diuretik, dan hydralazine. Labetalol adalah obat yang paling aman. Diuretik dan CCB (nifedipine) mungkin aman tetapi data minimal dan tidak digunakan sebagai firstline drug (Karthikeyan, 2015). Menurut ACC/AHA 2017 dan ESC/ESH 2018 obat antihipertensi pada kehamilan yang direkomendasikan hanya labetalol, methyldopa dan nifedipine, sedangkan yang dilarang adalah ACE inhibitor, ARB dan direct renin inhibitors (Aliskiren) (Williams, 2018). 


\subsection{Konsep Kecemasan}

\subsubsection{Defenisi kecemasan}

Kecemasan merupakan suatu respon psikologis maupun fisiologis individu terhadap suatu keadaan yang tidak menyenangkan, atau reaksi atas situasi yang dianggap mengancam (Hulu \& Pardede, 2016). Kecemasan merupakan suatu keadaan perasaan gelisah, ketidaktentuan, ada rasa takut dari kenyataan atau persepsi ancaman sumber aktual yang tidak diketahui masalahnya (Pardede \& Simangunsong, 2020). Kecemasan adalah perasaan ketakutan yang tidak memiliki penyebab yang jelas dan tidak didukung oleh situasi,kecemasan dapat dirasakan oleh setiap orang jika mengalami tekanan dan perasaan yang mendalam menyebabkan masalah kejiwaan dan berkembangan dalam jangka panjang ( Pardede, Simanjuntak \& Manulu, 2020)

Kecemasan merupakan keadaan emosional yang mempunyai ciri keterangsangan fisiologis perasaan yang tidak menyenngkan dan perasaan aprhensi atau keadaan khawatir yang mengeluhkan bahwa sesuatu yang buruk akan terjadi dengan ditandai oleh afek negatif dan gejala ketegangan jasmani dalam mengantisipasi datangnya bahaya (Nevid et al, 2018). Kecemasan adalah perasaan was-was, khawatir, takut yang tidak jelas atau tidak nyaman seakan-akan terjadi sesuatu yang mengancam. Kecemasan adalah perasaan tidak nyaman atau khawatir yang samar disertai otonom (sumber seringkali tidak spesifik atau tidak diketahui individu); perasaan takut yang disebabkan oleh antisipasi terhadap bahaya. Hal ini merupakan isyarat kewaspadaan yang memperingatkan individu akan adanya bahaya dan memampukan individu untuk bertindak menghadapi ancaman (NANDA, 2018). Kecemasan suatu kondisi perasaan yang berkaitan dengan ketakutan disertai gejala fisik seperti jantung berdebar nafas pendek atau nyeri dada, keringat dingin tangan geetaran yang dapat 
disebabkan oleh genetik, biokimia otak dan mekanisme fight-fight.( Febrianti, Hamid, \& Wardani, 2015)

Kecemasan mungkin hadir pada beberapa tingkat dalam kehidupan setiap individu, tetapi derajat dan frekuensi dengan yang memanifestasikan berbeda secara luas. Respon masing-masing individu memiliki kecemasan berbeda. Tepi emosional yang memprovokasi kecemasan untuk merangsang kreativitas atau kemampuan pemecahan masalah, yang lainnya dapat menjadi bergerak ke tingkat patologis. Perasaan umumnya dikategorikan menjadi empat tingkat untuk tujuan pengobatan : ringan, sedang, berat, dan panik. Perawat dapat menemukan klien cemas di mana saja di rumah sakit atau lingkup masyarakat.

\subsubsection{Etiologi kecemasan}

\section{Faktor predisposisi}

Stressor predisposisi adalah semua ketegangan dalam kehidupan yang dapat menyebabkan timbulnya kecemasan (Stuart, Keliat \& Pasaribu, 2016). Ketegangan dalam kehidupan tersebut dapat berupa

a. Peristiwa Traumatik, yang dapat memicu terjadinya kecemasan berkaitan dengan krisis yang dialami individu baik krisis perkembangan atau situasional.

b. Konflik Emosional, yang dialami individu dan tidak terselesaikan dengan baik. Konflik antara id dan superego atau antara keinginan dan kenyataan dapat menimbulkan kecemasan pada individu.

c. Konsep diri terganggu akan menimbulkan ketidakmampuan individu berpikir secara realitas sehingga akan menimbulkan kecemasan.

d. Frustasi akan menimbulkan rasa ketidakberdayaan untuk mengambil keputusan yang berdampak terhadap ego. 
e. Gangguan fisik akan menimbulkan kecemasan karena merupakan ancaman terhadap integritas fisik yang dapat mempengaruhi konsep diri individu.

f. Pola mekanisme koping keluarga atau pola keluarga menangani stress akan mempengaruhi individu dalam berespon terhadap konflik yang dialami karena pola mekanisme koping individu banyak dipelajari dalam keluarga.

g. Riwayat gangguan kecemasan dalam keluarga akan mempengaruhi respons individu dalam berespons terhadap konflik dan mengatasi kecemasannya.

h. Medikasi yang dapat memicu terjadinya kecemasan adalah pengobatan yang mengandung benzodiazepin, karena benzodiazepine dapat menekan neurotransmiter gamma amino butyric acid (GABA) yang mengontrol aktivitas neuron di otak yang bertanggung jawab menghasilkan kecemasan.

\section{Faktor presipitasi}

Stresor presipitasi adalah semua ketegangan dalam kehidupan yang dapat mencetuskan timbulnya kecemasan (Stuart, Keliat \& Pasaribu, 2016). Stressor presipitasi kecemasan dikelompokkan menjadi dua bagian, yaitu :

a. Ancaman terhadap integritas fisik. Ketegangan yang mengancam integritas fisik yang meliputi :

1) Sumber Internal, meliputi kegagalan mekanisme fisiologis sistem imun, regulasi suhu tubuh, perubahan biologis normal (misalnya : hamil).

2) Sumber Eksternal, meliputi paparan terhadap infeksi virus dan bakteri, polutan lingkungan, kecelakaan, kekurangan nutrisi, tidak adekuatnya tempat tinggal.

b. Ancaman terhadap harga diri meliputi sumber internal dan eksternal : 
1) Sumber Internal : kesulitan dalam berhubungan interpersonal di rumah dan tempat kerja, penyesuaian terhadap peran baru. Berbagai ancaman terhadap integritas fisik juga dapat mengancam harga diri.

2) Sumber Eksternal : kehilangan orang yang dicintai, perceraian, perubahan status pekerjaan, tekanan kelompok, sosial budaya.

\subsubsection{Rentang respon}

Menurut Stuart (2006) “menjelaskan rentang respon individu terhadap cemas berfluktuasi antara respon adaptif dan maladaptif. Rentang respon yang paling adaptif adalah antisipasi dimana individu siap siaga untuk beradaptasi dengan cemas yang mungkin muncul. Sedangkan rentang yang paling maladaptif adalah panik dimana individu sudah tidak mampu lagi berespon terhadap cemas yang dihadapi sehingga mengalami ganguan fisik, perilaku maupun kognitif. Seseorang berespon adaptif terhadap kecemasannya maka tingkat kecemasan yang dialaminya ringan, semakin maladaptif respon seseorang terhadap kecemasan maka semakin berat pula tingkat kecemasan yang dialaminya, seperti gambar dibawah ini :"

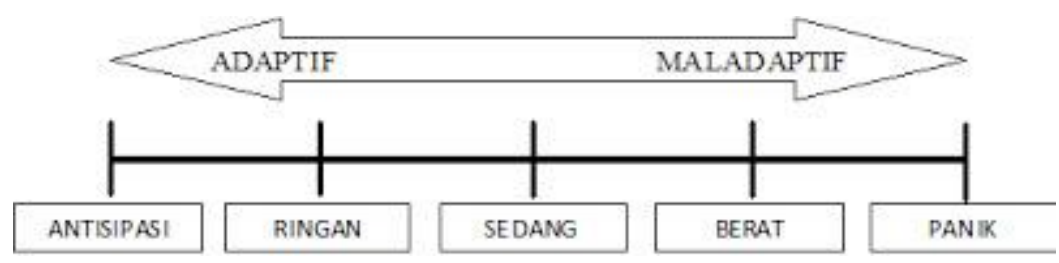

Gambar Rentang Respon Kecemasan (Stuart,2006) 


\subsubsection{Tanda dan Gejala Kecemasan}

Menurut Utami, Astuti\& Livana (2017) tanda dan gejala kecemasan adalah :

\section{Respons fisik :}

a. Kardiovaskular : Palpitasi, Jantung Bedebar, Tekanan Darah Meninggi, Denyut Nadi Cepat

b. Pernafasan : Napas Cepat, Napas Pendek, Tekanan Pada Dada, Napas Dangkal, Pembengkakan Pada Tenggorokan, TerengahEngah

c. Neuromuskular : Refleks Meningkat, Insomnia, Tremor, Gelisah, Wajah Tegang, Kelemahan Umum, Kaki Goyah, Gerakan Yang Janggal

d. Gastrointestinal : Anoreksia, Diare/Konstipasi, Mual, Rasa Tidak Nyaman Pada Abdomen

e. Traktur Urinarius : Sering Berkemih Dan Tidak Dapat Menahan Kencing

f. Kulit : Wajah Kemerahan, Berkeringat, Gatal, Rasa Panas Pada Kulit

\section{Respons Kognitif :}

Lapang persepsi menyempit, tidak mampu menerima rangsang luar, berfokus pada apa yang menjadi perhatiannya

\section{Respons Perilaku :}

Gerakan tersentak-sentak, bicara berlebihan dan cepat, perasaan tidak aman.

\section{Respons Emosi :}

Menyesal, iritabel, kesedihan mendalam, takut, gugup, sukacita berlebihan, ketidakberdayaan meningkat secara menetap, ketidakpastian, kekhawatiran meningkat, fokus pada diri sendiri, perasaan tidak adekuat, ketakutan, distressed, perihatin. 


\subsubsection{Penatalaksanaan Kecemasan}

Menurut Hawari (2008) penatalaksanaan ansietas pada tahap pencegahaan dan terapi memerlukan suatu metode pendekatan yang bersifat holistik, yaitu mencangkup fisik (somatik), psikologik atau psikiatrik, psikososial dan psikoreligius. Selengkpanya seperti pada uraian berikut :

1. Upaya meningkatkan kekebalan terhadap stress, dengan cara :

a. Makan makanan yang berigizi dan seimbang

b. Tidur yang cukup

c. Olahraga yang teratur

d. Tidak merokok dan tidak minum minuman keras

2. Terapi Psikofarmaka

Terapi psikofarmaka yang sering dipakai adalah obat anti cemas (anxiolytic), yaitu seperti diazepam, clobazam, bromazepam, lorazepam, buspirone $\mathrm{HCl}$, meprobamate dan alprazolam.

3. Terapi Somatik

Gejala atau keluhan fisik (somatik) sering dijumpai sebagai gejala ikutan atau akibat dari kecemasan yang bekerpanjangan. Untuk menghilangkan keluhan-keluhan somatik (fisik) itu dapat diberikan obat-obatan yang ditujukan pada organ tubuh yang bersangkutan.

4. Psikoterapi

Psikoterapi diberikan tergantung dari kebutuhan individu, antara lain
a. Psikoterapi Suportif
b. Psikoterapi Re-Edukatif
c. Psikoterapi Re-Konstruktif
d. Psikoterapi Kognitif
e. Psikoterapi Psikodinamik
f. Psikoterapi Keluarga

5. Terapi Psikoreligius 
Untuk meningkatkan keimanan seseorang yang erat hubungannya dengan kekebalan dan daya tahan dalam menghadapi berbagai problem kehidupan yang merupakan stressor psikososial.

\subsection{Konsep Asuhan Keperawatan}

\subsubsection{Pengkajian}

\section{Faktor Predisposisi}

Berbagai teori telah dikembangkan untuk menjelaskan asal ansietas (Waryuningsih,2021) :

\section{a. Teori Psikoanalitik}

Ansietas adalah konflik emosional yang terjadi antara dua elemen kepribadian, ID dan superego. ID mewakili dorongan insting dan impuls primitif seseorang, sedangkan superego mencerminkan hati nurani seseorang dan dikendalikan oleh norma- norma budaya seseorang. Ego atau Aku, berfungsi menengahi hambatan dari dua elemen yang bertentangan dan fungsi ansietas adalah mengingatkan ego bahwa ada bahaya

\section{b. Teori Interpersonal}

Ansietas timbul dari perasaan takut terhadap tidak adanya penerimaan dari hubungan interpersonal. Ansietas juga berhubungan dengan perkembangan, trauma seperti perpisahan dan kehilangan sehingga menimbulkan kelemahan spesifik.Orang dengan harga diri rendah mudah mengalami perkembangan ansietas yang berat.

\section{c. Teori Perilaku}

Ansietas merupakan produk frustasi yaitu segala sesuatu yang mengganggu kemampuan seseorang untuk mencapai tujuan yang diinginkan.Daftar tentang pembelajaran meyakini bahwa individu yang terbiasa dalam kehidupan dininya dihadapkan 
pada ketakutan yng berlebihan lebih sering menunjukkan ansietas pada kehidupan selanjutnya.

\section{d. Kajian Keluarga}

Menunjukkan bahwa gangguan ansietas merupakan hal yang biasa ditemui dalam suatu keluarga.Ada tumpang tindih dalam gangguan ansietas dan antara gangguan ansietas dengan depresi (Pardede, 2020).

\section{e. Kajian Biologis}

Menunjukkan bahwa otak mengandung reseptor khusus benzodiazepine. Reseptor ini mungkin membantu mengatur ansietas penghambat dalam aminobutirik. Gamma neuroregulator (GABA) juga mungkin memainkan peran utama dalam mekanisme biologis berhubungan dengan ansietas sebagaimana halnya endorfin. Selain itu telah dibuktikan kesehatan umum seseorang mempunyai akibat nyata sebagai predisposisi terhadap ansietas. Ansietas mungkin disertai dengan gangguan fisik dan selanjutnya menurunkan kapasitas seseorang untuk mengatasi stressor.

\section{Faktor Presipitasi}

Stressor pencetus mungkin berasal dari sumber internal atau eksternal. Stressor pencetus dapat dikelompokkan menjadi 2 kategori (Pratiwi, Widianti \& Solehati, 2017):

a. Ancaman terhadap integritas seseorang meliputi ketidakmampuan fisiologis yang akan datang atau menurunnya kapasitas untuk melakukan aktifitas hidup sehari- hari.

b. Ancaman terhadap sistem diri seseorang dapat membahayakan identitas, harga diri dan fungsi sosial yang terintegrasi seseorang. 


\section{Perilaku}

Kecemasan dapat diekspresikan secara langsung melalui perubahan fisiologi dan perilaku dan secara tidak langsung melalui timbulnya gejala atau mekanisme koping dalam upaya melawan kecemasan. Intensitas perilaku akan meningkat sejalan dengan peningkatan tingkat kecemasan.

a. Respon Fisiologis Terhadap Ansietas

\begin{tabular}{|c|c|}
\hline Sistem Tubuh & Respons \\
\hline Kardiovaskuler & $\begin{array}{l}\text { - Palpitasi. } \\
\text { - Jantung berdebar. } \\
\text { - Tekanan darah meningkat dan denyut nadi menurun. } \\
\text { - Rasa mau pingsan dan pada akhirnya pingsan. }\end{array}$ \\
\hline Pernafasan & $\begin{array}{l}\text { - } \text { Napas cepat. } \\
\text { - Pernapasan dangkal. } \\
\text { - Rasa tertekan pada dada. } \\
\text { - Pembengkakan pada tenggorokan. } \\
\text { - Rasa tercekik. } \\
\text { - Terengah-engah. }\end{array}$ \\
\hline Neuromuskular & $\begin{array}{ll}\text { - } & \text { Peningkatan reflek. } \\
\text { - } & \text { Reaksi kejutan. } \\
\text { - } & \text { Insomnia. } \\
\text { - } & \text { Getakutan. } \\
\text { - } & \text { Wajah tegang. } \\
\text { - } & \text { Kelemahan secara umum. } \\
\text { - } & \text { Gerakan lambat. } \\
\text { - } & \text { Gerakan yang janggal. } \\
\end{array}$ \\
\hline Gastrointestinal & $\begin{array}{l}\text { - Kehilangan nafsu makan. } \\
\text { - Menolak makan. } \\
\text { - Perasaan dangkal. } \\
\text { - Rasa tidak nyaman pada abdominal. } \\
\text { - Rasa terbakar pada jantung. } \\
\text { - Nausea. } \\
\text { - } \text { Diare. }\end{array}$ \\
\hline Perkemihan & $\begin{array}{l}\text { - } \quad \text { Tidak dapat menahan kencing. } \\
\text { - } \quad \text { Sering kencing. }\end{array}$ \\
\hline Kulit & $\begin{array}{l}\text { - } \text { Rasa terbakar pada mukosa. } \\
\text { - } \text { Berkeringat banyak pada telapak tangan. } \\
\text { - } \text { Patal-gatal. } \\
\text { - Perasaan panas atau dingin pada kulit. }\end{array}$ \\
\hline
\end{tabular}


- Muka pucat dan bekeringat diseluruh tubuh.

b. Respon Perilaku Kognitif

\begin{tabular}{|c|c|}
\hline Sistem & Respons \\
\hline Perilaku & $\begin{array}{l}\text { - } \text { Gelisah. } \\
\text { - Ketegangan fisik. } \\
\text { - } \text { Tremor. } \\
\text { - Gugup. } \\
\text { - } \text { Bicara cepat. } \\
\text { - Kecenderungan untuk celaka. } \\
\text { - Menarik diri. } \\
\text { - Menghindar. } \\
\text { - Terhambat melakukan aktifitas. }\end{array}$ \\
\hline Kognitif & $\begin{array}{l}\text { - } \text { Gangguan perhatian. } \\
\text { - } \text { Konsentrasi hilang. } \\
\text { - } \text { Pelupa. } \\
\text { - Salah tafsir. } \\
\text { - } \text { Adanya bloking pada pikiran. } \\
\text { - } \text { Menurunnya lahan persepsi. } \\
\text { - Kreatif dan produktif menurun. } \\
\text { - } \text { Bingung. }\end{array}$ \\
\hline & $\begin{array}{l}\text { - Khawatir yang berlebihan. } \\
\text { - Hilang menilai objektifitas. } \\
\text { - Takut akan kehilangan kendali. } \\
\text { - Takut yang berlebihan. }\end{array}$ \\
\hline Afektif & $\begin{array}{l}\text { - } \text { Mudah terganggu. } \\
\text { - Tidak sabar. } \\
\text { - Gelisah. } \\
\text { - Tegang. } \\
\text { - Nerveus. } \\
\text { - Ketakutan. } \\
\text { - Alarm. } \\
\text { - Tremor. } \\
\text { - Gugup. } \\
\text { - Gelisah. }\end{array}$ \\
\hline
\end{tabular}

\section{Sumber Koping}

Individu dapat mengalami stress dan ansietas dengan menggerakkan sumber koping tersebut di lingkungan. Sumber koping tersebut sebagai modal ekonomok, kemampuan penyelesaian masalah, dukungan sosial dan keyakinan budaya 
dapat membantu seseorang mengintegrasikan pengalaman yang menimbulkan stress dan mengadopsi strategi koping yang berhasil (Rahayu, 2016).

\section{Mekanisme Koping}

Ketika mengalami ansietas individu menggunakan berbagai mekanisme koping untuk mencoba mengatasinya dan ketidakmampuan mengatasi ansietas secara konstruktif merupakan penyebab utama terjadinya perilaku patologis. Ansietas tingkat ringan sering ditanggulangi tanpa yang serius.

Tingkat ansietas sedang dan berat menimbulkan 2 jenis mekanisme koping :

a. Reaksi yang berorientasi pada tugas, yaitu upaya yang disadari dan berorientasi pada tindakan untuk memenuhi secara realitis tuntutan situasi stress.

b. Mekanisme pertahanan ego, membantu mengatasi ansietas ringan dan sedang, tetapi jika berlangsung pada tingkat sadar dan melibatkan penipuan diri dan distorsi realitas, maka mekanisme ini dapat merupakan respon maladaptif terhadap stress.

\subsubsection{Diagnosa Keperawatan}

Adapun diagnosa yang biasanya muncul adalah :

1. Koping Individu Tidak Efektif

2. Kecemasan

3. Ketidakberdayaan

4. Isolasi Sosial

5. Perubahan Proses Berfikir

\subsubsection{Intervensi Keperawatan}

\section{Kecemasan}

Tujuan : 
- Klien mampu mengenal pengertian penyebab tanda gejala dan akibat

- Klien mampu mengetahui cara mengatasi ansietas

- Klien mampu mengatasi ansietas dengan melakukan latihan relaksasi tarik nafas dalam

- Klien mampu mengatasi ansietas dengan melakukan latihan distraksi

- Klien mampu mengatasi ansietas dengan melakukan hipnotis lima jari

- Klien mampu merasakan manfaat dari latihan yang dilakukan

- Klien mampu membedakan perasaan sebelum dan sesudah latihan

Tindakan :

a. Kaji tanda dan gejala ansietas dan kemampuan klien mengurangi kecemasan

b. Jelaskan tanda dan gejala, penyebab dan akibat dari kecemasan

c. Latihan cara mengatasi kecemasan :

1) Teknik relaksasi napas dalam

2) Distraksi : bercakap-cakap hal positif

3) Hipnotis 5 jari fokus padahal-hal yang positif

d. Bantu klien melakukan latihan sesuai dengan jadwal kegiatan.

\section{Koping tidak efektif}

Tujuan :

- Klien mampu mengetahui perubahan kondisi kesehatan dan kemampuannya mengatasi perubahan

- Klien mampu mengetahui pengertian tanda dan gejala penyebab serta akibat dari ketidakefektifan koping

- Klien mampu mengetahui cara mengatasi ketidakefektifan koping

- Klien mampu mengatasi masalah secara bertahap 
- Klien mampu menggunakan sumber/daya sistem pendukung dalam mengatasi masalah

- Klien mampu merasakan manfaat latihan yang dilakukan

- Klien mampu mengembangkan koping yang efektif klien mampu merasakan manfaat sistem pendukung

Tindakan :

a. Kaji tanda dan gejala ketidakefektifan koping

b. Jelaskan proses terjadinya ketidakefektifan koping

c. Diskusikan koping (upaya atau cara) mengatasi masalah pada masa lalu

d. Koping (upaya) yang berhasil dan tidak berhasil. Berikan pujian

e. Pemanfaatan sumber daya atau sistem pendukung dalam mengatasi masalah

f. Latihan menggunakan upaya menyelesaikan masalah saat ini dengan menggunakan cara lama yang berhasil atau cara baru.

- Buat daftar masalah yang dihadapi

- Buat daftar cara (lama dan baru) yang akan digunakan

- Pilih, latih, dan jadwalkan cara yang akan digunakan untuk masalah yang dihadapi

- Evaluasi hasil jika berhasil dibudidayakan jika kurang berhasil dipilih cara lain pada daftar cara nomor kedua

g. Latih menggunakan sistem pendukung yang teratur

h. Beri motivasi dan pujian atas keberhasilan klien mengatasi masalah

\section{Gangguan citra tubuh}

Tujuan :

- Klien mampu mengenal bagian tubuh yang sehat dan yang terganggu atau sakit

- Klien mampu mengetahui cara mengatasi gangguan citra tubuh

- Klien mampu mengafirmasi bagian tubuh yang sehat

- Klien mampu melatih dan menggunakan bagian tubuh yang 
sehat

- Klien mampu merawat dan melatih bagian tubuh yang terganggu

- Klien mampu mengevaluasi manfaat yang telah dirasakan dari bagian tubuh yang terganggu

- Klien mampu mengevaluasi manfaat bagian tubuh yang masih sehat

- Klien mampu merasakan manfaat latihan pada bagian tubuh yang terganggu

Tindakan :

a. Kaji tanda dan gejala gangguan citra tubuh dan kemampuan klien mengatasinya.

b. Jelaskan tanda dan gejala, penyebab dan akibat gangguan citra tubuh

c. Diskusikan persepsi, perasaan, dan harapan klien terhadap citra tubuhnya

d. Menjelaskan perubahan-perubahan fisik yang terjadi pada ibu hamil

e. Motivasi klien untuk merawat dan meningkatkan citra tubuh seperti : menggunakan make up dan skincare untuk wajah yang berjerawat.

f. Motivasi klien untuk melakukan latihan meningkatkan citra tubuh sesuai jadwal dan beri pujian. 
BAB 3

TINJAUAN KASUS

\subsection{PENGKAJIAN KEPERAWATAN}

\begin{tabular}{|c|c|}
\hline $\begin{array}{l}\text { Nama : Ny. E } \\
\text { Usia : } 27 \text { tahun } \\
\text { Tahun no reg : - } \\
\text { Ruangan : - } \\
\text { Tgl masuk rs: - } \\
\text { Tgl pengkajian : } 30 \text { September } 2021 \\
\text { Alamat : Setiabudi }\end{array}$ & $\begin{array}{l}\text { Kondisi saat ini : } \\
\text { Saat pengkajian klien mengatakan ia memiliki riwayat } \\
\text { penyakit hipertensi dan saat ini klien sedang hamil } \\
\text { (primigravida) trimester ke II. Klien mengatakan merasa } \\
\text { cemas dengan keadaannya karena selalu pusing, mual dan } \\
\text { muntah setiap makanan masuk, ia khawatir janinnya tidak } \\
\text { mendapatkan nutrisi yang cukup. Klien mengatakan } \\
\text { kurang percaya diri dengan perubahaan fisik yang } \\
\text { dialaminya seperti sekarang, dimana perutnya semakin } \\
\text { membesar, kaki membengkak, dan timbulnya jerawat di } \\
\text { dahinya berbeda ketika klien belum hamil. Klien } \\
\text { mengatakan jika selama hamil ia sulit tidur dan sering } \\
\text { bangun pada tengah malam. }\end{array}$ \\
\hline
\end{tabular}




\subsubsection{FAKTOR PREDISPOSISI DAN FAKTOR PRESIPITASI}

\begin{tabular}{|c|c|c|c|c|}
\hline \multirow[t]{2}{*}{ Faktor predisposisi } & \multicolumn{3}{|l|}{ Faktor presipitasi } & \multirow[t]{2}{*}{ STRESSOR } \\
\hline & Nature & Origin & Number \& Timing & \\
\hline $\begin{array}{l}\text { Biologis: } \\
\text { - Klien mengatakan tidak ada } \\
\text { riwayat penyakit keluarga } \\
\text { - } \quad \text { Klien sedang hamil trimester ke } \\
\text { II saat ini } \\
\text { - } \text { Klien mengatakan sudah } 2 \text { tahun } \\
\text { mengidap penyakit Hipertensi } \\
\text { tapi gejala yang dialami tidak } \\
\text { sampai seperti ini. }\end{array}$ & $\begin{array}{l}\text { - } \text { Badan lemas, } \\
\text { nyeri pada ulu } \\
\text { hati, mual }\end{array}$ & Internal & $\begin{array}{l}\text { Saat dilakukan } \\
\text { pengkajian }\end{array}$ & - Hipertensi \\
\hline $\begin{array}{l}\text { Psikologis : } \\
\text { - Ny. E memiliki kepribadian } \\
\text { yang terbuka setiap ada masalah } \\
\text { akan dibicarakan dengan } \\
\text { suaminya }\end{array}$ & $\begin{array}{lr}\text { - Cemas } & \text { dan } \\
\text { khawatir } & \text { karena } \\
\text { penyakitnya } & \text { klien } \\
\text { harus } & \text { rutin } \\
\text { konsumsi } & \text { obat }\end{array}$ & Internal & $\begin{array}{l}\text { Sejak } 3 \text { bulan yang } \\
\text { lalu }\end{array}$ & $\begin{array}{l}\text { - Ansietas, } \\
\text { takut, } \\
\text { khawatir, } \\
\text { kurang } \\
\text { percaya diri }\end{array}$ \\
\hline
\end{tabular}




\begin{tabular}{|c|c|c|}
\hline 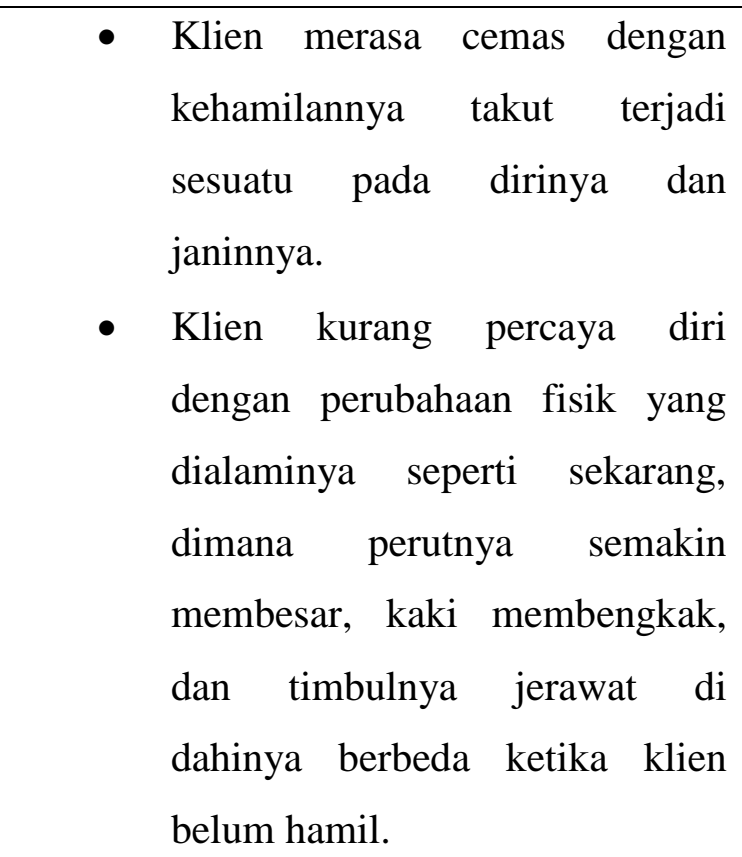 & $\begin{array}{lr}\text { dalam } & \text { keadaan } \\
\text { hamil. } & \\
\text { - } & \text { Klien kurang } \\
\text { percaya diri } & \text { dengan perubahaan } \\
\text { fisik yang } \\
\text { dialaminya }\end{array}$ & \\
\hline $\begin{array}{l}\text { Sosiocultural : } \\
\begin{array}{l}\text { - } \\
\text { Klien seorang perempuan umur } 27 \\
\text { tahun } \\
\text { - Klien sudah menikah dan sedang } \\
\text { hamil } \\
\text { - Ny. E merupakan ibu rumah tangga } \\
\text { - Klien merupakan orang Nias dan }\end{array}\end{array}$ & . & - \\
\hline
\end{tabular}




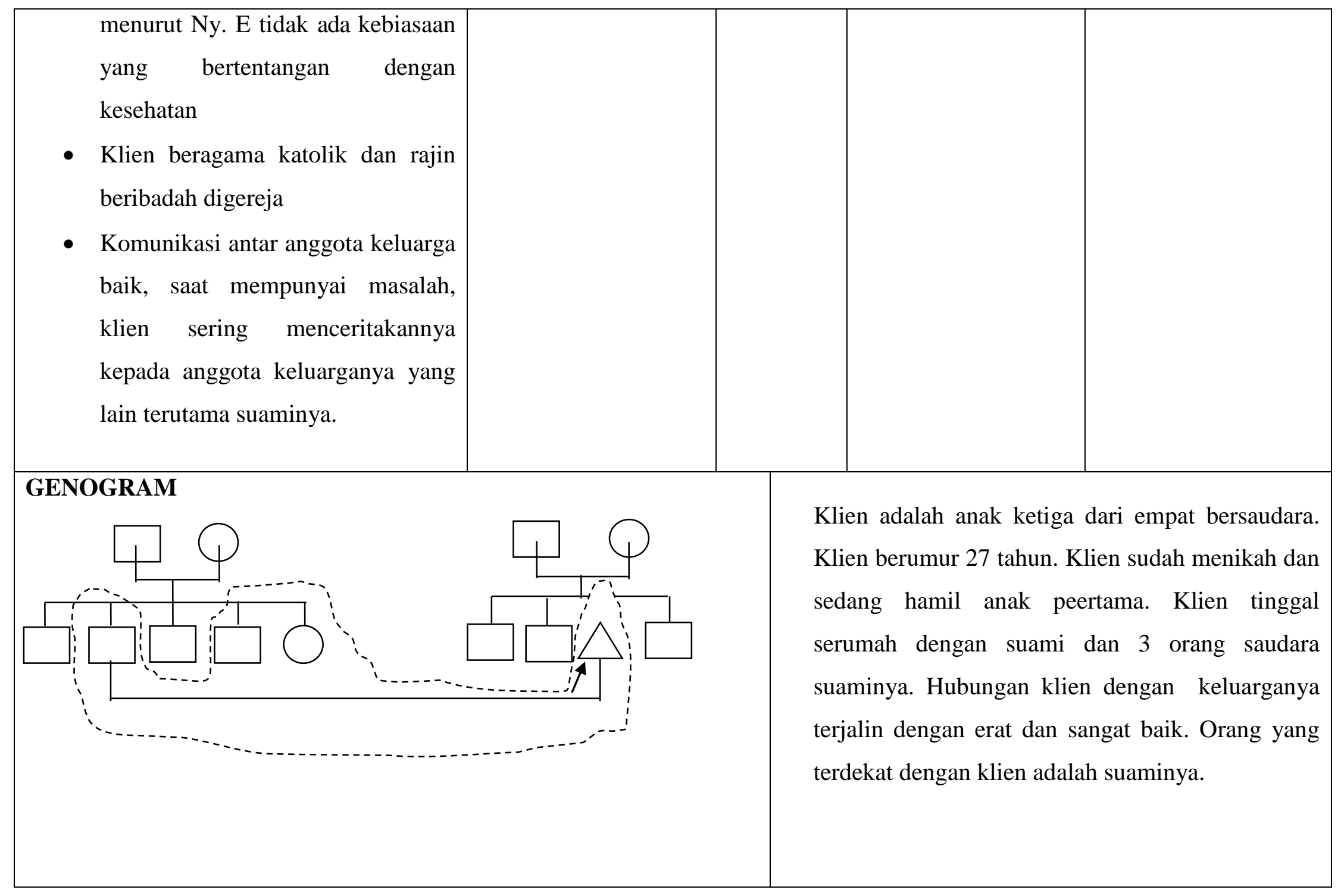




\begin{tabular}{|ll|l|}
\hline & $=$ Laki-laki \\
$=$ Perempuan & $=$ Hamil \\
\hline & $=$ Tinggal satu rumah \\
& $=$ Klien \\
& $=$ Meninggal
\end{tabular}


3.1.2 PENILAIAN (RESPON) TERHADAP STRESSOR

\begin{tabular}{|c|c|c|c|c|c|c|}
\hline STRESSOR & KOGNITIF & AFEKTIF & FISIOLOGIS & PERILAKU & SOSIAL & $\begin{array}{l}\text { DIAGNOSA } \\
\text { KEPERAWA } \\
\text { TAN }\end{array}$ \\
\hline $\begin{array}{r}\text { BIOLOGIS } \\
\text { - }(\text { Hipertensi) }\end{array}$ & $\begin{array}{l}\text { - Menurut } \\
\text { klien } \\
\text { penyakit } \\
\text { gastritisnya } \\
\text { diakibatkan } \\
\text { karena sering } \\
\text { terlambat } \\
\text { makan } \\
\text { - Menganggap } \\
\text { penyakit } \\
\text { yang } \\
\text { diderita } \\
\text { berbahaya } \\
\text { apalagi ia } \\
\text { sedang } \\
\text { hamil. }\end{array}$ & $\begin{array}{l}\text { - Adanya rasa } \\
\text { cemas dan } \\
\text { khawatir } \\
\text { karena klien } \\
\text { mengidap } \\
\text { penyakit } \\
\text { gastritis dan } \\
\text { harus rutin } \\
\text { konsumsi obat } \\
\text { dalam } \\
\text { keadaan } \\
\text { hamil. }\end{array}$ & 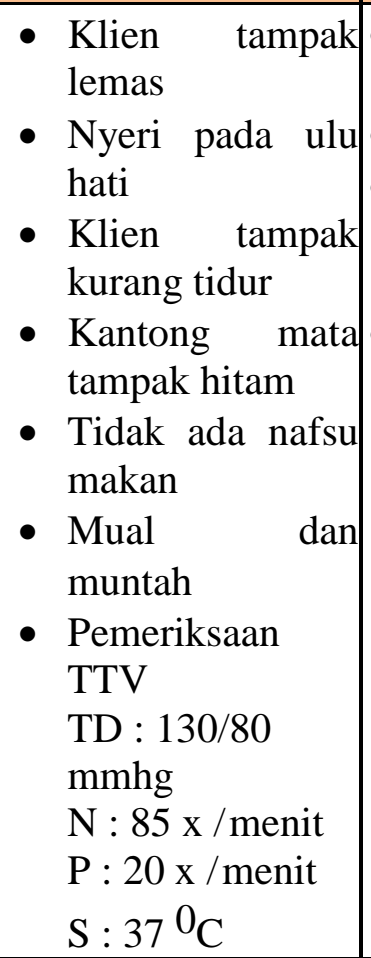 & $\begin{array}{l}\text { - } \text { Cemas, mondar } \\
\text { mandir } \\
\text { - } \text { Bicara cepat } \\
\text { - } \text { Klien merasa } \\
\text { perasaannya } \\
\text { tidak aman } \\
\text { - Klien tampak } \\
\text { gelisah }\end{array}$ & $\begin{array}{l}\text { Klien } \\
\text { ketempat } \\
\text { pelayanan } \\
\text { kesehatan } \\
\text { dan } \\
\text { menggunaka } \\
\text { n fasilitas } \\
\text { kesehatan } \\
\text { untuk } \\
\text { mendapatkan } \\
\text { perawatan. }\end{array}$ & - Ansietas \\
\hline
\end{tabular}




\begin{tabular}{|c|c|c|c|c|c|c|}
\hline \begin{tabular}{|l} 
PSIKOLOGIS \\
Cemas \\
dengan \\
kehamilannya \\
takut terjadi \\
sesuatu pada \\
dirinya dan \\
janinnya. \\
Klien kurang \\
percaya diri \\
dengan \\
perubahaan \\
fisik \\
dialaminya \\
seperti badan \\
semakin \\
gemuk, kaki \\
membengkak \\
dan \\
tumbuhnya
\end{tabular} & $\begin{array}{l}\text { - Klien tahu } \\
\text { bahwa } \\
\text { badannya } \\
\text { menjadi } \\
\text { lemas } \\
\text { merupakan } \\
\text { dampak dari } \\
\text { penyakit yang } \\
\text { dideritanya } \\
\text { - Klien tahu } \\
\text { bahwa } \\
\text { perubahan } \\
\text { fisik yang } \\
\text { dialaminya } \\
\text { merupakan } \\
\text { hal biasa } \\
\text { yang dialami } \\
\text { ibu hamil } \\
\text { akan tetapi } \\
\text { klien tetap } \\
\text { kurang diri } \\
\text { percaya diri }\end{array}$ & $\begin{array}{ll}\text { - } & \text { Takut dan } \\
& \text { khawatir } \\
\text { - } & \text { Kurang } \\
& \text { percaya diri }\end{array}$ & $\begin{array}{ll}\text { - } & \text { Mual dan } \\
& \text { muntah } \\
\text { - } & \text { Tampak lemas } \\
\text { - } & \text { Berkeringat } \\
\text { banyak } & \\
\text { - } & \text { Kaki klien } \\
\text { tampak } \\
\text { membengkak } \\
\text { dan ada jerawat } \\
\text { disekitar wajah }\end{array}$ & $\begin{array}{l}\text { - Tampak cemas, } \\
\text { gelisah dan } \\
\text { tidak tenang } \\
\text { - Klien sedih saat } \\
\text { bercerita } \\
\text { - Klien kurang } \\
\text { percaya diri } \\
\text { - Kontak mata } \\
\text { kurang }\end{array}$ & 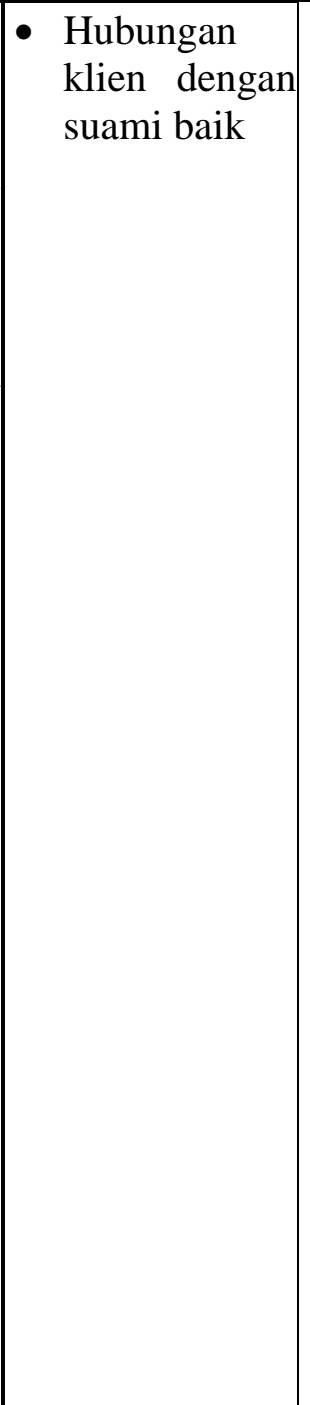 & $\begin{array}{ll}\text { - } & \text { Ansietas } \\
\text { - } & \text { Gangguan } \\
& \text { citra tubuh }\end{array}$ \\
\hline
\end{tabular}




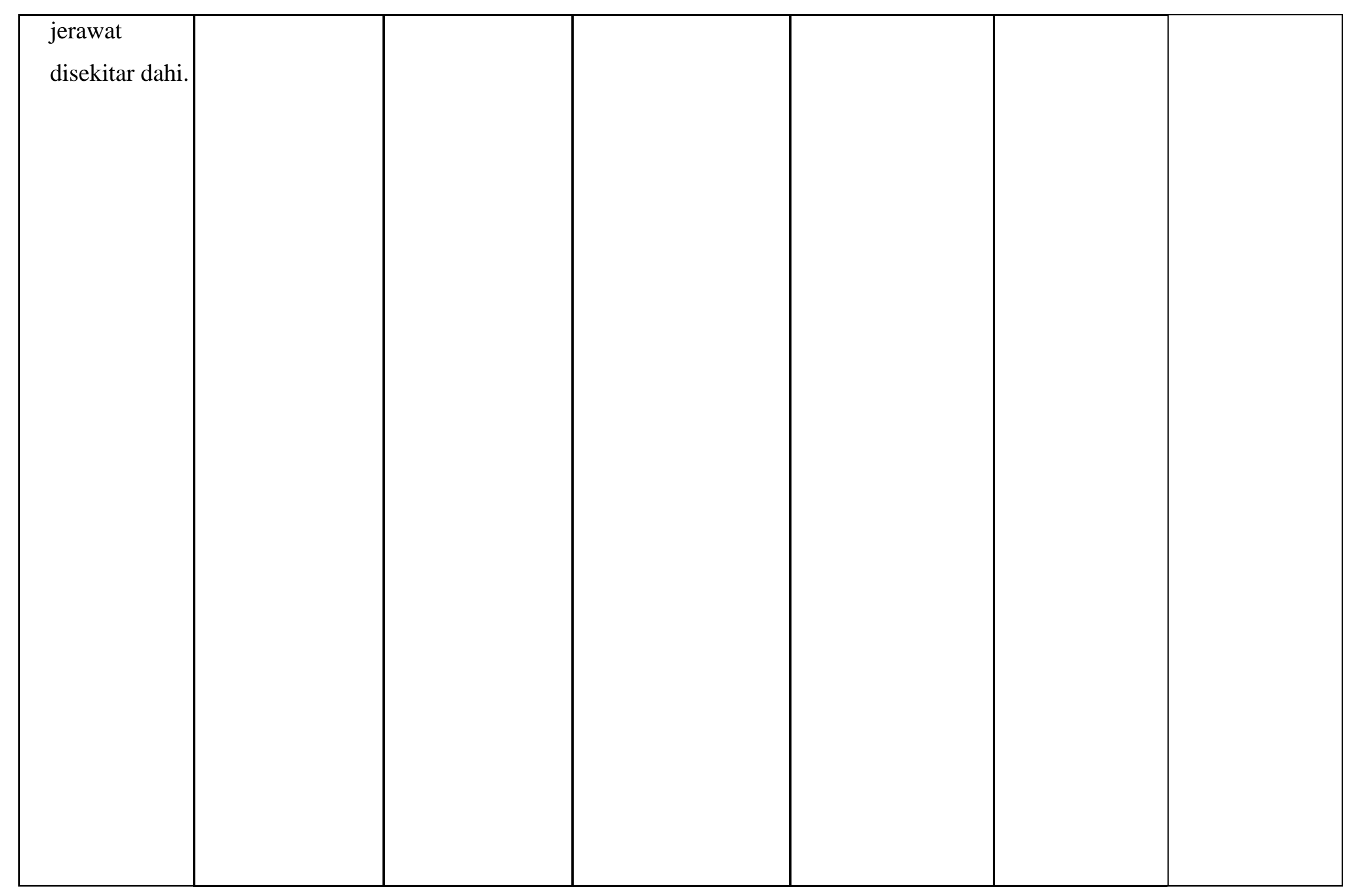




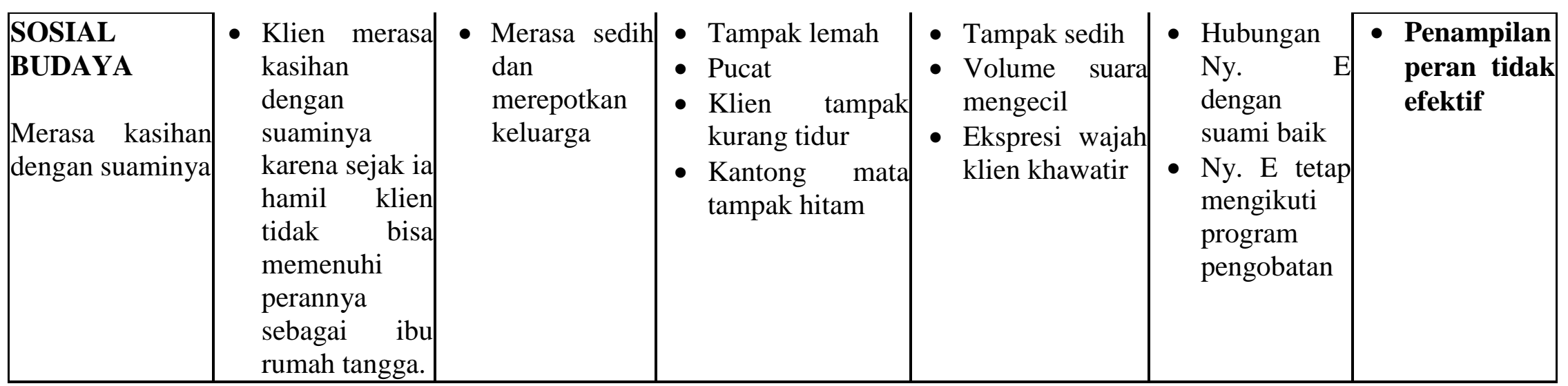




\subsubsection{SUMBER KOPING}

\begin{tabular}{|c|c|c|c|c|c|}
\hline $\begin{array}{c}\text { DIAGNOSA } \\
\text { KEPERAWATAN }\end{array}$ & $\begin{array}{c}\text { PERSONAL } \\
\text { ABILITY }\end{array}$ & $\begin{array}{c}\text { SOSIAL } \\
\text { SUPPORT }\end{array}$ & $\begin{array}{c}\text { MATERIAL } \\
\text { ASSETS }\end{array}$ & $\begin{array}{l}\text { POSITIVE } \\
\text { BELIEFS }\end{array}$ & TERAPI \\
\hline Kecemasan & 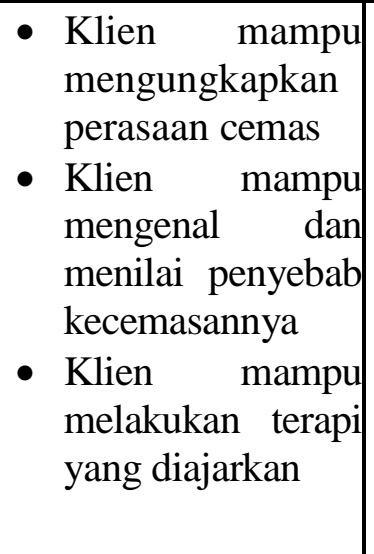 & $\begin{array}{l}\text { - Klien mendapat } \\
\text { dukungan dari } \\
\text { keluarga untuk } \\
\text { kesembuhanny } \\
\text { a terutama dari } \\
\text { suaminya }\end{array}$ & 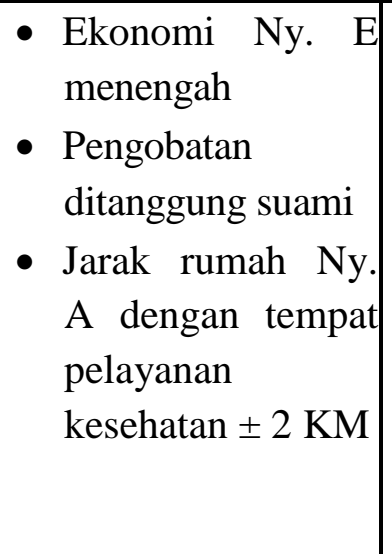 & $\begin{array}{l}\text { - Klien percaya } \\
\text { bahwa petugas } \\
\text { kesehatan akan } \\
\text { membantunya } \\
\text { - } \text { Klien berharap } \\
\text { cepat sembuh } \\
\text { agar c tidak } \\
\text { merepotkan } \\
\text { suami dan } \\
\text { keluarganya }\end{array}$ & \begin{tabular}{|l} 
Terapi generalis : \\
SP 1-4 kecemasan \\
untuk individu \\
Terapi spesialis : \\
Relaksasi \\
progresif \\
Psikoedukasi \\
keluarga
\end{tabular} \\
\hline
\end{tabular}




\begin{tabular}{|c|c|c|c|c|c|}
\hline $\begin{array}{l}\text { Penampilan peran } \\
\text { tidak efektif }\end{array}$ & $\begin{array}{l}\text { - Klien dapat } \\
\text { menyebutkan } \\
\text { penyebab } \\
\text { penampilan peran } \\
\text { tidak efektif } \\
\text { - Klien } \\
\text { menganggap } \\
\text { suami tidak } \\
\text { mampu sebagai } \\
\text { pengganti akibat } \\
\text { kondisi yang } \\
\text { berubah }\end{array}$ & $\begin{array}{l}\text { - Klien mendapat } \\
\text { dukungan dari } \\
\text { keluarga untuk } \\
\text { kesembuhanny } \\
\text { a terutama dari } \\
\text { suaminya }\end{array}$ & $\begin{array}{l}\text { - Ekonomi Ny. E } \\
\text { menengah } \\
\text { - Pengobatan } \\
\text { ditanggung suami } \\
\text { - Jarak rumah Ny. } \\
\text { A dengan tempat } \\
\text { pelayanan } \\
\text { kesehatan } \pm 2 \mathrm{KM}\end{array}$ & 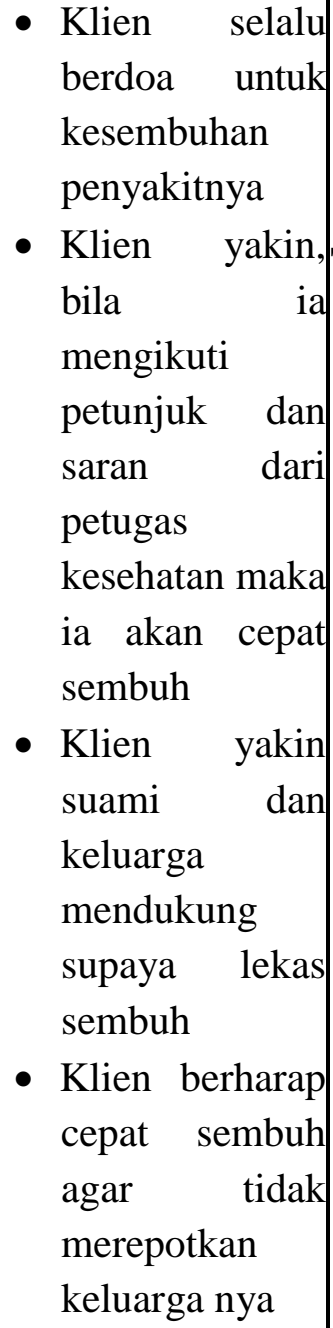 & $\begin{array}{l}\text { Terapi generalis : } \\
\text {-SP } 1-2 \text { penampilan } \\
\text { peran tidak efektif } \\
\text { Terapi spesialis : } \\
\text { - Behavior therapy, } \\
\text { rerapi suportif }\end{array}$ \\
\hline
\end{tabular}




\begin{tabular}{|c|c|c|c|c|c|}
\hline \begin{tabular}{|l|l|}
$\begin{array}{l}\text { Gangguan } \\
\text { tubuh }\end{array}$ & citra \\
\end{tabular} & \begin{tabular}{lr}
$\begin{array}{lr}\text { Klien } \\
\text { percaya }\end{array}$ & kurang \\
dengan & diri \\
perubahaan & fisik \\
\multicolumn{2}{l}{ yang dialaminya }
\end{tabular} & 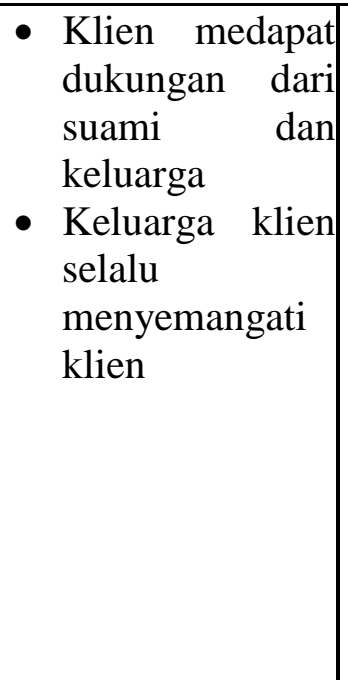 & \begin{tabular}{ll} 
- Sosial ekonomi \\
\multicolumn{2}{l}{ klien menengah } \\
- Sarana dan \\
prasarana tersedia \\
- $\begin{array}{ll}\text { Biaya } \\
\text { pengobatan }\end{array}$ \\
ditanggung oleh \\
suami
\end{tabular} & $\begin{array}{l}\text { - Klien percaya } \\
\text { bahwa petugas } \\
\text { kesehatan akan } \\
\text { membantunya } \\
\text { - Klien berharap } \\
\text { cepat sembuh } \\
\text { agar percaya } \\
\text { diri lagi } \\
\text { - Klien selalu } \\
\text { berdoa untuk } \\
\text { kesembuhan } \\
\text { penyakitnya }\end{array}$ & $\begin{array}{l}\begin{array}{l}\text { Terapi generalis: } \\
\text { gangguan } \\
\text { tubuh }\end{array} \\
\text { Terapi spesialis: } \\
\text { - Terapi kognitif }\end{array}$ \\
\hline
\end{tabular}




\subsubsection{MEKANISME KOPING}

\begin{tabular}{|c|c|}
\hline HAL YANG DILAKUKAN & ANALISA \\
\hline $\begin{array}{l}\text { - Klien mengatakan bila ada masalah, maka ia akan } \\
\text { membicarakan dengan suami dan keluarga untuk mencari jalan } \\
\text { keluarnya } \\
\text { - Bila sakit klien berobat ke pelayanan kesehatan } \\
\text { - Klien taat menjalankan ibadah sesuai dengan keyakinannya } \\
\text { - Klien selalu berdoa kepada TYM untuk kesembuhan dan } \\
\text { kesehatan janinnya }\end{array}$ & $\begin{array}{l}\text { - Konstruktif: } \\
\checkmark \text { Klien mengatakan bila ada masalah, maka ia akan } \\
\text { membicarakan dengan suami dan keluarga untuk } \\
\text { mencari jalan keluarnya } \\
\checkmark \text { Bila sakit klien berobat ke pelayanan kesehatan } \\
\checkmark \text { Klien taat menjalankan ibadah sesuai dengan } \\
\text { keyakinannya } \\
\checkmark \text { Klien selalu berdoa kepada TYM untuk kesembuhan } \\
\text { dan kesehatan janinnya } \\
\text { Destruktif : - }\end{array}$ \\
\hline
\end{tabular}




\subsubsection{STATUS MENTAL}

\begin{tabular}{|l|l|}
\hline 1. Penampilan & Bersih, rapi, tidak tercium bau. \\
\hline 2. Pembicaraan & Berbicara dengan jelas \\
\hline 3. Aktivitas motoric & Saat wawancara pasien tampak gelisah \\
\hline $\begin{array}{l}\text { 4. Interaksi } \\
\text { selamawawancara }\end{array}$ & Cukup kooperatif \\
\hline 5. Alam perasaan & Klien tampak menunjukkan ekspresi takut dan khawatir \\
\hline 6. Afek & Sesuai dengan stimulus yang diberikan \\
\hline 7. Persepsi & Klien tidak mengalami gangguan persepsi dan sensori \\
\hline 8. Isi pikir & Sesuai realita \\
\hline 9. Proses pikir & Baik \\
\hline 10. Tingkat kesadaran & Normal (compos mentis) \\
\hline 11. Daya ingat & Klien dapat mengingat kejadian dalam jangka waktu yang lama \\
\hline 12. Kemampuan berhitung & Klien mampu berhitung \\
\hline 13. Penilaian & Klien mampu melakukan penilaian terhadap dirinya sendiri \\
\hline 14. Daya tilik diri & Klien menyadari bahwa saat ini ia sedang sakit dan sedang hamil. \\
& \\
\hline
\end{tabular}


Kesimpulan : Mental Status Examination (MSE) tidak ada masalah gangguan jiwa, gangguan Ny.A lebih kepada Gangguan Mental Emosional (GME/Psikososial)

\subsection{DIAGNOSA DAN TERAPI}

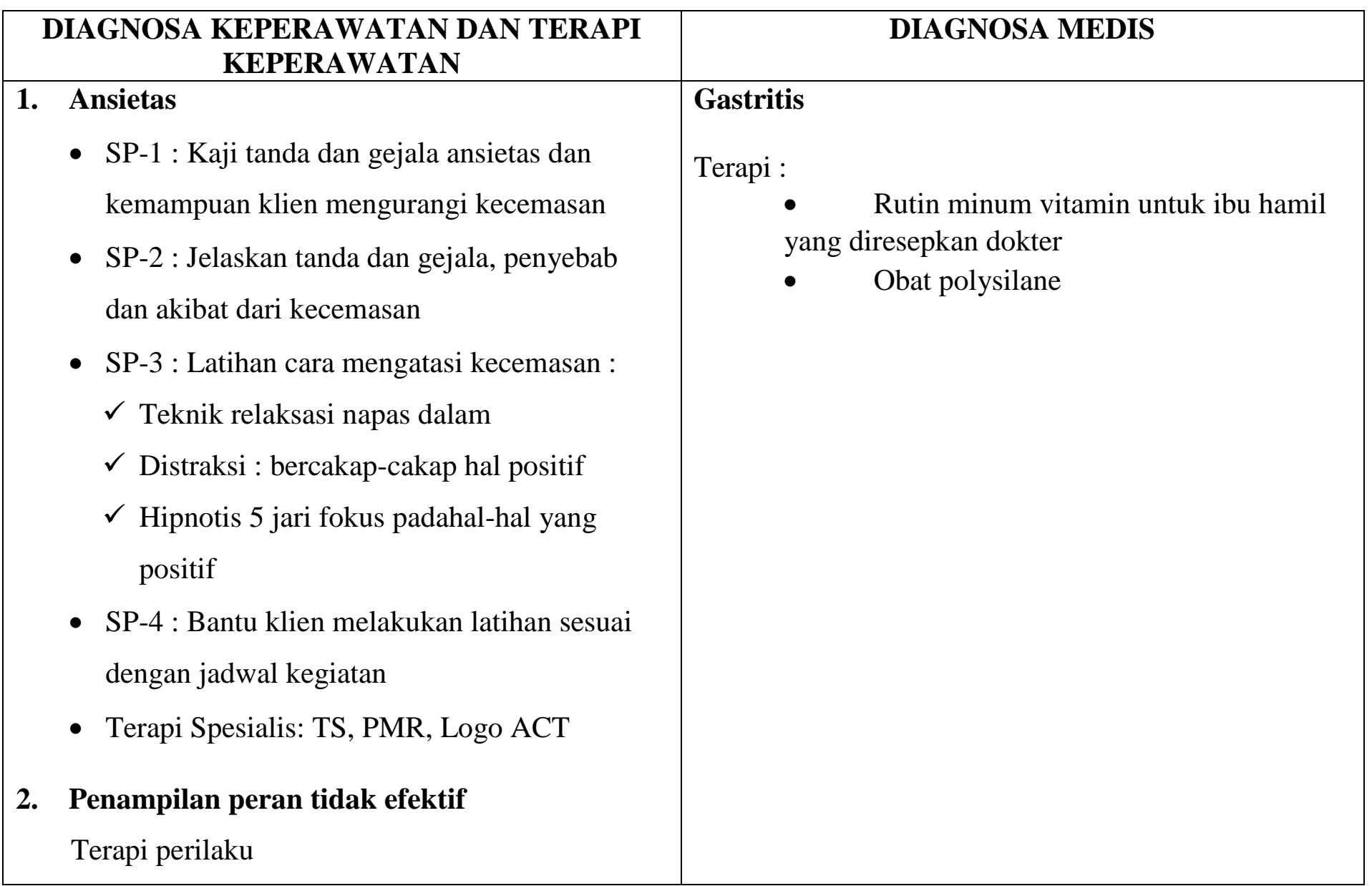




\begin{tabular}{|l|l|}
\hline 3. Gangguan citra tubuh \\
- Kaji tanda dan gejala gangguan citra tubuh dan \\
kemampuan klien mengatasinya. \\
- Jelaskan tanda dan gejala, penyebab dan akibat \\
gangguan citra tubuh \\
- Diskusikan persepsi, perasaan, dan harapan \\
klien terhadap citra tubuhnya \\
- Menjelaskan perubahan-perubahan fisik yang \\
terjadi pada ibu hamil \\
- Motivasi klien untuk merawat dan \\
meningkatkan citra tubuh seperti : \\
menggunakan make up dan skincare untuk \\
wajah yang berjerawat. \\
- Motivasi klien untuk melakukan latihan \\
meningkatkan citra tubuh sesuai jadwal dan \\
beri pujian.
\end{tabular}




\subsection{IMPLEMENTASI TINDAKAN KPERAWATAN DAN EVALUASI}

\begin{tabular}{|c|c|}
\hline $\begin{array}{l}\text { IMPLEMENTASI TINDAKAN } \\
\text { KEPERAWATAN }\end{array}$ & EVALUASI \\
\hline $\begin{array}{l}\text { Tanggal : } 01 \text { September } 2021 \\
\text { Jam : } 10.00 \text { wib } \\
\text { e. Kaji tanda dan gejala ansietas dan kemampuan } \\
\text { klien mengurangi kecemasan } \\
\text { f. Jelaskan tanda dan gejala, penyebab dan akibat } \\
\text { dari kecemasan } \\
\text { g. Latihan cara mengatasi kecemasan : } \\
\text { 4) Teknik relaksasi napas dalam } \\
\text { 5) Distraksi : bercakap-cakap hal positif } \\
\text { 6) Hipnotis } 5 \text { jari fokus padahal-hal yang positif } \\
\text { h. Bantu klien melakukan latihan sesuai dengan } \\
\text { jadwal kegiatan. }\end{array}$ & 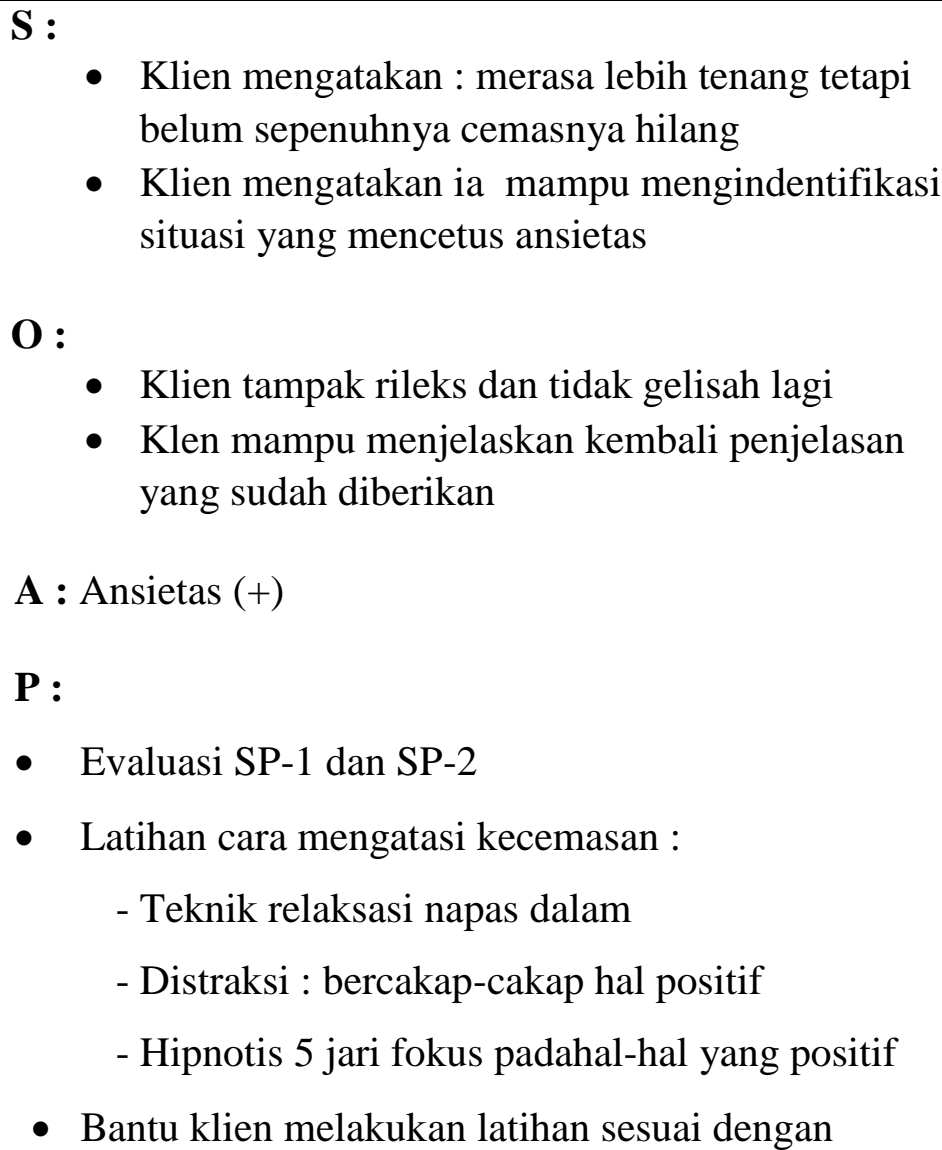 \\
\hline
\end{tabular}




\begin{tabular}{|c|c|}
\hline & jadwal kegiatan \\
\hline $\begin{array}{l}\text { Tanggal : } 02 \text { September } 2021 \\
\text { Jam : } 10.00 \text { wib } \\
\text { a. Latihan cara mengatasi kecemasan : } \\
\text { - Teknik relaksasi napas dalam } \\
\text { - Distraksi : bercakap-cakap hal positif } \\
\text { - Hipnotis } 5 \text { jari fokus padahal-hal yang positif } \\
\text { b. Bantu klien melakukan latihan sesuai dengan } \\
\text { jadwal kegiatan. }\end{array}$ & $\begin{array}{l}\text { S : } \\
\text { - Klien mengatakan : merasa lebih tenang dan } \\
\text { - } \text { tidak merasa cemas lagi } \\
\text { - Klien mengatakan ia mampu mengindentifikasi } \\
\text { - } \text { Situasi yang mencetus ansietas } \\
\text { - } \text { tarik mapas dalam } \\
\text { - Klien mengatakan sudah bisa melakukan teknik } \\
\text { - } \text { distraksi } \\
\text { Klien mengatakan sudah bisa melakukan teknik } \\
\text { Oipnotis } 5 \text { jari } \\
\text { - Klien tampak rileks dan tidak gelisah lagi } \\
\text { - Klen mampu menjelaskan kembali penjelasan } \\
\text { - Kang sudah diberikan } \\
\text { - Klien mampu melakukan teknik napas dalam } \\
\text { - Klien mampu melakukan distraksi }\end{array}$ \\
\hline
\end{tabular}




\begin{tabular}{|c|c|}
\hline & 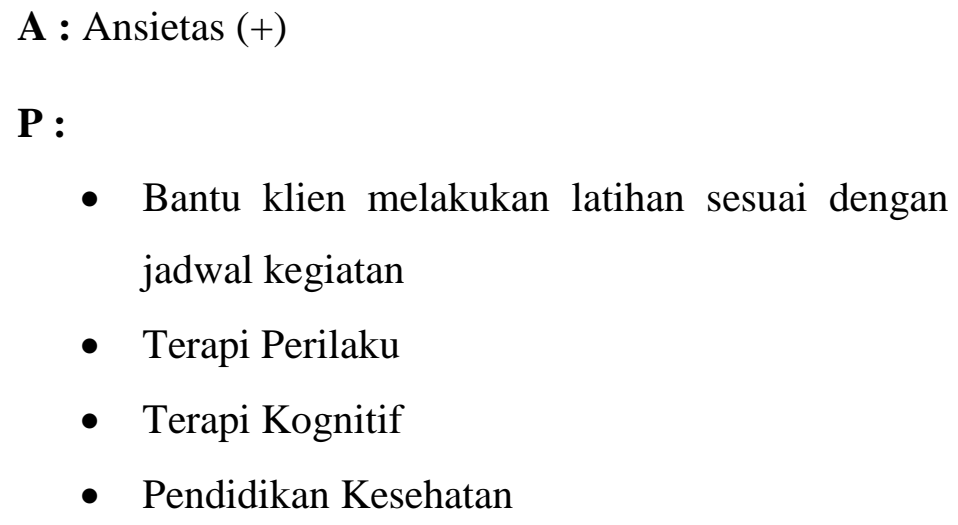 \\
\hline $\begin{array}{l}\text { Tanggal : } 03 \text { September } 2021 \\
\text { Jam : } 10.00 \text { wib } \\
\text { a. Latihan cara mengatasi kecemasan : } \\
\text { - Teknik relaksasi napas dalam } \\
\text { - Distraksi : bercakap-cakap hal positif } \\
\text { - Hipnotis } 5 \text { jari fokus padahal-hal yang positif } \\
\text { b. Bantu klien melakukan latihan sesuai dengan } \\
\text { jadwal kegiatan. }\end{array}$ & $\begin{array}{l}\text { S : pasien mengatakan kecemasan sedikit berkurang, } \\
\text { mampu mengatas kecemasan, dengan intervensi yang } \\
\text { diberikan } \\
\text { O: Pasien masih terlihat dengan kecemasan yang belum } \\
\text { teratasi, tidak mampu melakukan teknik relaksasi fisik } \\
\text { Tarik nafas dalam, dan distraksi hipnotis lima jari } \\
\text { A: kecemasan pasien belum Teratasi } \\
\text { P: Intervensi dilanjutkan }\end{array}$ \\
\hline $\begin{array}{l}\text { Tanggal : 04 September } 2021 \\
\text { Jam : } 10.00 \text { wib } \\
\text { a. Latihan cara mengatasi kecemasan : } \\
\text { - Teknik relaksasi napas dalam }\end{array}$ & $\begin{array}{l}\text { S: pasien masih malu akan penyakitnya, namun pasien } \\
\text { terihat mau berkomunikasi kepada suami. } \\
\text { O: pasien terlihat masih merasa harga dirinya rendah, } \\
\text { tidak mampu mengidentifikasi masalahnya sendiri } \\
\text { A: harga diri pasien belum teratasi } \\
\text { P: intervensi dilanjutkan }\end{array}$ \\
\hline
\end{tabular}




\begin{tabular}{|c|c|}
\hline $\begin{array}{l}\text { - Distraksi : bercakap-cakap hal positif } \\
\text { - Hipnotis } 5 \text { jari fokus padahal-hal yang positif } \\
\text { b. Bantu klien melakukan latihan sesuai dengan } \\
\text { jadwal kegiatan. }\end{array}$ & \\
\hline $\begin{array}{l}\text { Tanggal : } 05 \text { September } 2021 \\
\text { Jam : } 10.00 \text { wib } \\
\text { a. Latihan cara mengatasi kecemasan : } \\
\text { - Teknik relaksasi napas dalam } \\
\text { - Distraksi : bercakap-cakap hal positif } \\
\text { - Hipnotis } 5 \text { jari fokus padahal-hal yang positif } \\
\text { b. Bantu klien melakukan latihan sesuai dengan } \\
\text { jadwal kegiatan. }\end{array}$ & $\begin{array}{l}\text { S: Pasien mengatakan: ansietasnya belum teratasi } \\
\text { karena pasien masih beum merasa tenang, masih } \\
\text { cemas, dan masih merasa tidak berdaya. } \\
\text { O: pasien terlihat masih merasa tidakberdaya akan } \\
\text { penyakitnya, belum mampu mengindentifikasi situasi } \\
\text { pecentus dari ansietas } \\
\text { A: Ketidakberdayaan pasien belum berkurang } \\
\text { P: intervensi dilanjutkan }\end{array}$ \\
\hline $\begin{array}{l}\text { Tanggal : } 06 \text { September } 2021 \\
\text { Jam : } 10.00 \text { wib } \\
\text { a. Latihan cara mengatasi kecemasan : } \\
\text { - Teknik relaksasi napas dalam } \\
\text { - Distraksi : bercakap-cakap hal positif } \\
\text { - Hipnotis } 5 \text { jari fokus padahal-hal yang positif } \\
\text { b. Bantu klien melakukan latihan sesuai dengan } \\
\text { jadwal kegiatan. }\end{array}$ & 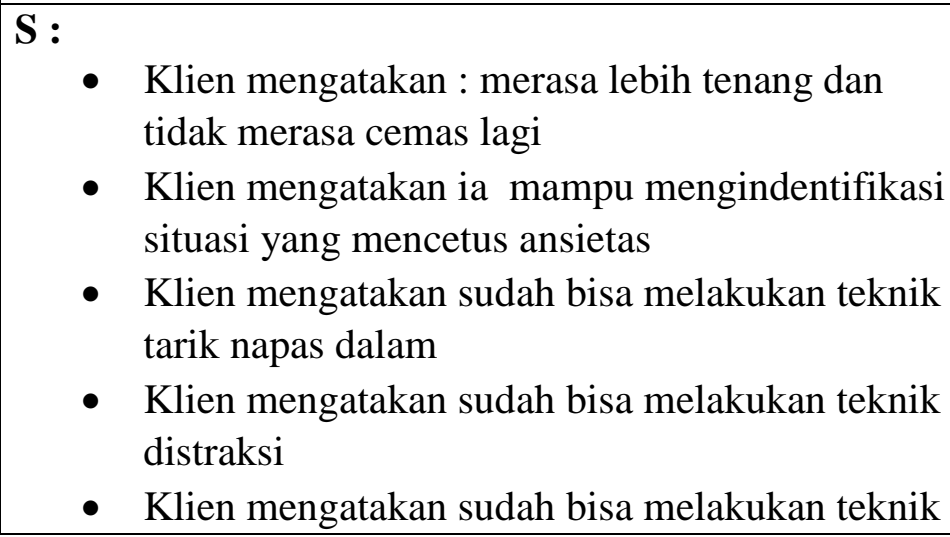 \\
\hline
\end{tabular}




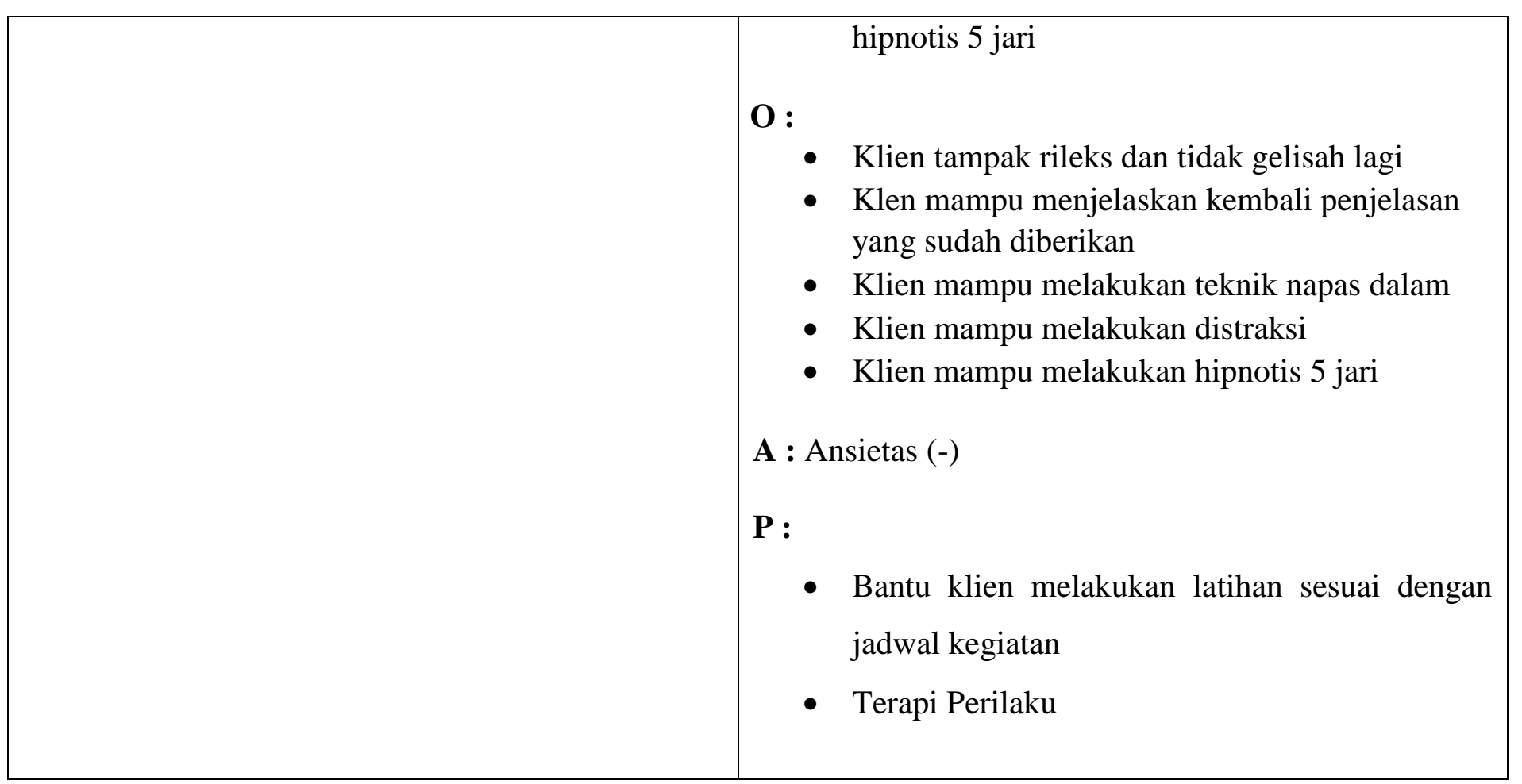




\section{BAB 4}

\section{PEMBAHASAN}

Setelah penulis melaksanakan asuhan keperawatan kepada Ny.E dengan Kecemasan di jalan Setia budi maka penulis pada BAB ini akan membahasan kesenjangan antara teoritis dengan tinjauan kasus. Pembahasan dimulai melalui tahapan proses keperawatan yaitu pengkajian, diagnosa keperawatan, perencanaan, pelaksanaan dan evaluasi.

\subsection{Tahap Pengkajian}

Selama pengkajian dilakukan pengumpulan data dari beberapa sumber, yaitu dari pasien dan tetangga sekitar. Maka penulis melakukan pendekatan kepada pasien melalui komunikasi teraupetik yang lebih terbuka membantu klien untuk memecahkan perasaannya dan juga melakukan observasi kepada pasien. Adapun upaya tersebut yaitu :

a. Melakukan pendekatan dan membina hubungan saling percaya diri pada klien agar klien lebih terbuka dan lebih percaya dengan menggunakan perasaan.

b. Mengadakan pengkajian klien dengan wawancara Dalam pengkajian ini, penulis tidak menemukan kesenjangan karena ditemukan hal sama seperti: diteori: Ketidakberdayaan adalah persepsi atau tanggapan klien bahwa perilaku atau tindakan yang sudah dilakukannya tidak akan membawa hasil yang diharapkan atau tidak akan membawa perubahan hasil seperti yang diharapkan, sehingga klien sulit mengendalikan situasi yang terjadi atau mengendalikan situasi yang akan terjadi.

\subsection{Tahap perencanaan}

Perencanaan dalam proses keperawatan lebih dikenal dengan rencana asuhan keperawatan yang merupakan tahap selanjutnya setelah pangkajian dan penentuan diagnosa keperawatan. Pada tahap perencanaan penulis hanya menyusun rencana tindakan keperawatan sesuai dengan pohon masalah keperawatan yaitu :Ketidakberdayaan. Pada tahap ini antara 
tinjauan teoritis dan tinjaun kasus tidak ada kesenjangan sehingga penulis dapat melaksanakan tindakan seoptimal mungkin dan didukung dengan seringnya bimbingan dengan pembimbing.

Secara teoritis digunakan cara strategi pertemuan sesuai dengan diagnosa keperawatan yang muncul saat pengkajian. Adapun upaya yang dilakukan penulis yaitu :

1. Klien mengungkapkan ketidakpastian tentang fluktuasi tingkat energi dan bersikap pasif.

2. Klien menunjukan sikap apatis, depresi terhadap perburukan fisik yang terjadi dengan mengabaikan kepatuhan pasien terhadap program pengobatan

Klien mengalami ketergantungan pada orang lain yang dapat mengakibatkan ititabilitas, ketidaksukaan, marah dan rasa bersalah. Klien tidak melakukan praktik perawatan diri ketika ditantang. Klien tidak ikut memantau kemajuan pengobatan. Klien menunjukan ekspresi ketidakpuasan terhadap ketidakmampuan melakukan aktivitas atau tugas sebelumnya. Klien menunjukan ekspresi keraguan tantang performa peran 


\subsection{Tahap Implementasi}

Pada tahap implementasi, penulis hanya mengatasi 1 masalah keperawatan yakni: diagnosa keperawatan Ketidakberdayaan merupakan perasaan yang absolut yang di ekspresikan melalui sikap dimana seseorang atau klien akan menghadapi suatu situasi dengan mengeksplorasi pengalaman perasaan ketidakberdayaannya termasuk dalam menghadapi tren isu yang turut menjadi penyebab rasa tidak berdaya.

\subsection{Tahap Evaluasi}

Pada tinjauan teoritis evaluasi yang diharapkan adalah :

a. Membina hubungan saling percaya

b. Mengenali dan mengekspresikan emosinya

c. Memodifikasi pola kognitif yang negative

d. Berpartisipasi dalam pengambilan keputusan yang berkenaan dengan perawatannya sendiri.

e. Termotivasi untuk aktif mencapai tujuan yang realistis. 


\section{BAB 5}

\section{PENUTUP}

\subsection{Kesimpulan}

Berdasarkan konsep asuhan keperawatan yang telah disusun dan dilaksanakan kepada Ny.E dimiliki dari pengkajian, rumusan masalah, perencanaan, pelaksanaan hingga evaluasi didapat hasil bahwa Ny.E dengan keluhan utama cemas akan Penyakit diabetes melitus sehingga tidak mampu melakukan aktivitas seperti biasanya Data objektif yaitu klien tampak Badan lemas,kesemutan, gatal, gemetaran pusing luka yang lama sembuh, Kadar glukosa darah tinggi Dari masalah masalah diatas maka diperoleh prioritas masalah yang diangkat adalah tentang kebutuhan rasa aman nyaman yang berfokus pada cemas. Kemudian diberikan intervensi secara konsep yaitu terapi teknik relaksasi napas dalam, terapi distraksi, hipnotis lima jari dan pendidikan kesehatan. Dari hasil implementasi ada beberapa intervensi yang berhasil teratasi seperti klien mengatakan sudah lebih tenang dan cemas nya sedikit berkurang dan mampu mengenali gejala, tanda, penyebab dan akibat dari kecemasan. Sedangkan klien masih bingung dalam melakukan terapi hipnotis lima jari maka intervensi dilanjutkan.

\subsection{Saran}

Diharapkan bagi perawat selalu berkoordinasi dengan tenaga kesehatan lainnya dalam memberikan asuhan keperawatan agar lebih maksimal terkusus pada klien dengan kecemasan pada pasien Hipertensi 


\section{DAFTAR PUSTAKA}

1. Raihan, L. N., \& Dewi, A. P. (2015). Faktor-faktor yang berhubungan dengan kejadian hipertensi primer pada masyarakat di wilayah kerja Puskesmas Rumbai Pesisir (Doctoral dissertation, Riau University).

2. Yuwono, G. A., Ridwan, M., \& Hanafi, M. (2018). Pengaruh Pendidikan Kesehatan Tentang Hipertensi Terhadap Tingkat Kecemasan Pada Penderita Hipertensi Di Kabupaten Magelang. Jurnal Keperawatan Soedirman, 12(1), 55-66. http://dx.doi.org/10.20884/1.jks.2017.12.1.687

3. Ariyanti, R. (2020). Gambaran Tingkat Kecemasan Pada Ibu Hamil Dengan Hipertensi Kehamilan Di Puskesmas Karangrejo Tarakan. Jakiyah: Jurnal Ilmiah Umum dan Kesehatan Aisyiyah, 5(1), 29-34.

4. Trisiani, D. (2016). Hubungan Kecemasan Ibu Hamil terhadap Kejadian Preeklampsia. Jurnal Ilmiah Bidan, 1(3), 14-18.

5. Alatas, H. (2019). Hipertensi pada Kehamilan. Herb-Medicine Journal, 2(2), 27-51.

6. Riskesdas .(2018). Kementrian Kesehatan Republik Indonesia, Riset Kesehatan Dasar 2018

7. Zaini, M. (2019). Asuhan keperawatan Jiwa Masalah Psikososial Di Pelayanan Klinis dan Komunitas. Deepublish : Yogyakarta.

8. Oxyandi, M., Fitrayani, C., \& Nurhayati, N. (2018). Ubungan Umur, Komunikasi Terapeutik Perawat Dan Dukungan Keluarga Terhadap Tingkat Kecemasan Pasien Pre Operatif Di Ruang Marwah Rumah Sakit Islam Siti Khadijah Palembang Tahun 2018. Jurnal Kesehatan Lentera'Aisyiyah, 1(1), $1-12$.

9. Hulu, E. K., \& Pardede, J. A. (2016). Dukungan Keluarga Dengan Tingkat Kecemasan Pasien Pre Operatif Di Rumah Sakit Sari Mutiara Medan. Jurnal Keperawatan, 2(1).

10. Pardede, J. A., \& Simangunsong, M. M. (2020). Family Support With The Level of Preschool Children Anxiety in the Intravenous Installation. Jurnal Keperawatan Jiwa (JKJ): Persatuan Perawat Nasional Indonesia, 8(3), 223-234. https://doi.org/10.26714/jkj.8.3.2020.223-234

11. Pardede, J. A. (2020). Standar Asuhan Keperawatan Jiwa Dengan Masalah Kecemasan.

12. Pardede, J., Simanjuntak, G. V., \& Manalu, N. (2020). Effectiveness of deep breath relaxation and lavender aromatherapy against preoperative patient 
anxiety. Diversity and Equality in Health and Care, 17(4), 168-173.

13. Nevid, J. S., \& Gordon, A. J. (2018). Integrated learning systems: Is there a learning benefit?. Teaching of Psychology, 45(4), 340-345.

14. Nanda, S. N. (2018). Asuhan Kebidanan Continuity Of Care Pada Ny. S Dengan Keputihan Di PMB Hj. Farida hajri s. St surabaya (Doctoral dissertation, Universitas Muhammadiyah Surabaya).

15. Stuart. Gail. W, Keliat. Budi. Anna,\& Pasaribu. Jesika.(2016). Keperawatan kesehal11tan jiwa: Indonesia : Elsever.

16. Febrianti, D., Hamid, A. Y. S., \& Wardani, I. Y. (2015). Gambaran Asuhan Keperawatan Pada Klien Hipertensi Dengan Ansietas Menggunakan Pendekatan Uncertainty in Illness Dan Comfort Theory. Jurnal Ilmu Kesehatan, 7(2), 113-118.

17. Sari, H. (2015). Penerapan Terapi Kelompok Suportif Pada Ibu Hamil Dengan Ansietas Melalui Pendekatan Teori Mercer Di Kelurahan Balumbang Jaya, Bogor Barat. Idea Nursing Journal,2(2), 153161. https://doi.org/10.52199/inj.v2i2.6375

18. Pratiwi, S. R., Widianti, E., \& Solehati, T. (2017). Gambaran faktor-faktor yang berhubungan dengan kecemasan pasien kanker payudara dalam menjalani kemoterapi. Jurnal Pendidikan Keperawatan Indonesia, 3(2), 167-174.

19. Utami, T. W., Astuti, Y. S., \& Livana, P. H. (2017). Hubungan Kecemasan Dengan Depresi Pada Anak Sekolah Dasar. Jurnal Keperawatan, 9(1), 1-5.

20. Pardede, J. A. (2020). Terapi Keluarga.

21. Naja, G., Halasz, A., Thiboutot, S., Ampleman, G., \& Hawari, J. (2008). Degradation of hexahydro-1, 3, 5-trinitro-1, 3, 5-triazine (RDX) using zerovalent iron nanoparticles. Environmental science \& technology, 42(12), 4364-4370.

22. Rahayu, N. W. (2016). Studi Kasus pada Klien Ansietas dengan Pendekatan Teori Adaptasi Stuart.

23. Pardede, J. A., Sitepu, S. F. A., \& Saragih, M. (2018). The Influence of Deep Breath Relaxation Techniques and Five-Finger Hypnotic Therapy on Preoperative Patient Anxiety. Journal of Psychiatry, 3(1), 1-8.

24. Malha et al., (2018). Hypertension in Pregnancy in Hypertension: A Companion to Braunwald's Heart Disease (Third Edition) Ch 39. Elsevier. 
25. Kementerian Kesehatan Republik Indonesia., (2018). Profil Kesehatan Indonesia Tahun (2017). Kemenkes RI.

26. Pardede, J. A., Hafizuddin, H., \& Sirait, A. (2021). Coping Strategies Related to Self-Esteem on PLWHA in Medan Plus Foundation. Jurnal Ilmu Keperawatan Jiwa, 4(2), 255-262.

27. Karthikeyan, V.J., (2015). Hypertension in pregnancy; in Nadar, S. and Lip, G.Y.H., Hypertension, Ch. 22, 2nd Ed. Oxford Cardiology Library. Oxford.

28. Nadar, S., (2015). Pathophysiology of hypertension in Oxford Cardiology Library Hypertension 2 nd Edition Ch 2. Oxford University Press. https://doi.org/10.1016/j.ehj.2003.08.021 